\title{
Article \\ Geophysical and Geochemical Characterization of Solidwaste Dumpsite: A Case Study of Chowa Gujar, Peshawar (Part of Indus Basin)
}

\author{
Nabeel Afzal Butt ${ }^{1}$, Muhammad Younis Khan ${ }^{1} \mathbb{1}$, Seema Anjum Khattak ${ }^{1}$, Gulraiz Akhter ${ }^{2,3, *}{ }^{\mathbb{D}}$, \\ Yonggang Ge ${ }^{4,5, * \mathbb{D}}$, Muhammad Tahir Shah ${ }^{1}$ and Asam Farid ${ }^{6}$
}

check for

updates

Citation: Butt, N.A.; Khan, M.Y.;

Khattak, S.A.; Akhter, G.; Ge, Y.;

Shah, M.T.; Farid, A. Geophysical and Geochemical Characterization of Solidwaste Dumpsite: A Case Study of Chowa Gujar, Peshawar (Part of Indus Basin). Sustainability 2022, 14, 1443. https://doi.org/10.3390/ su14031443

Academic Editor: Jesus Martinez -Frias

Received: 27 December 2021

Accepted: 22 January 2022

Published: 27 January 2022

Publisher's Note: MDPI stays neutral with regard to jurisdictional claims in published maps and institutional affiliations.

Copyright: () 2022 by the authors Licensee MDPI, Basel, Switzerland. This article is an open access article distributed under the terms and conditions of the Creative Commons Attribution (CC BY) license (https:/ / creativecommons.org/licenses/by/ $4.0 /)$.
1 National Centre of Excellence in Geology, University of Peshawar, Peshawar 25120, Pakistan; nabeel.qau1@gmail.com (N.A.B.); myouniskhan@uop.edu.pk (M.Y.K.); s_anjum@uop.edu.pk (S.A.K.); tahir_shah@uop.edu.pk (M.T.S.)

2 China-Pakistan Joint Research Center on Earth Sciences, CAS-HEC, Islamabad 45320, Pakistan

3 Department of Earth Sciences, Quaid-i-Azam University, Islamabad 45320, Pakistan

4 Institute of Mountain Hazards and Environment, Chinese Academy of Sciences, Chengdu 610041, China

5 Key Laboratory of Mountain Hazards and Earth Surface Processes, Chinese Academy of Sciences, Chengdu 610041, China

6 Arab Company for Laboratories and Soil, Al Khobar 34217, Saudi Arabia; asam.farid@gmail.com

* Correspondence: agulraiz@qau.edu.pk (G.A.); gyg@imde.ac.cn (Y.G.)

\begin{abstract}
Open and non-engineered dumping is a typical method for solid waste disposal in most cities of Pakistan. This practice of waste dumping poses a serious threat to the surrounding ecosystem and human population due to the release and transport of decomposed organic matter, i.e., leachate from dumpsite into the groundwater. The present study was conducted over a non-engineered and open dumpsite (Chowa Gujar), located in the outskirts of the highly populated city of Peshawar by using integrated geophysical techniques such as electrical resistivity tomography (ERT) and ground-penetrating radar (GPR) and geochemical techniques. The main goal was to delineate the characterization and depth of buried waste, to map the subsurface extension of contaminant plumes towards agricultural land and groundwater table and the concentration of heavy metals (HMs) in dump and agricultural soil. Geophysical results showed that the thickness of buried waste (predominantly composed of domestic waste) was around $4 \mathrm{~m}$ and the leachate plumes have percolated to the adjacent agricultural land. A range of heavy metals $(\mathrm{mg} / \mathrm{kg})$ such as $\mathrm{Cr}(20.5-26.6)$, $\mathrm{Cd}$ (2.6-5.7), Pb (0.35-21.25), Ni (2.5-53.05), Cu (29-68.3), Zn (45.7-77), and Co (18.9-23.2) have been found in the agricultural land adjacent to the dumpsite. The findings demonstrated that combined use of ERT and GPR successfully characterize the buried waste and spread of pollutant plumes spatially and vertically from Chowa Gujar dumpsite. The anomalous geophysical signatures were confirmed by geochemical characterization. The movement of leachate plumes towards agricultural land and groundwater table and the concentration of HMs in soil show that Chowa Gujar dumpsite is a potential source of contamination not only to the surrounding population but also to the agricultural land, surface (Bara River), and subsurface water bodies. In the study region, there is an urgency to take remediation and mitigation measures to reduce the level of pollution created by the dumpsite.
\end{abstract}

Keywords: ERT; GPR; geochemistry; domestic waste; leachate plumes; heavy metals

\section{Introduction}

Municipal solid waste (MSW) management is an internationally identified environmental issue in major populated areas, especially in developing countries, Therefore it has been highlighted in United Nations Sustainable development goals (SDG's); the main aim of these SDG's is to reduce such threats by 2030 [1]. The world's urban population is estimated to exceed 6 billion by 2045, specifically in the countries of the developing world [2]. Pakistan's most recent census, conducted in 2017, counted 208 million people, 
representing an annual population growth rate of 2.4 percent since the last census in 1998 [3]. The urbanization and increasing population growth will result in several challenges, e.g., MSW management across the globe, especially in developing countries. In Pakistan, solid waste generation varies from 0.283 to $0.613 \mathrm{~kg}$ per person per day, with a waste generation increasing rate of 3.67 to 7.42 percent each year [4]. Open dumpsites are considered a cheap source for MSW disposal. The main challenges in managing these sites include weak government policies, lack of interest in social, and industrial organizations. This has led to poor waste management systems in ever-expanding metropolitan cities like Peshawar. Currently, there are several open dumpsites in Peshawar which are generally situated very close to the rivers and their tributaries, for instance the Chowa Gujar dumpsite is lying adjacent to the Bara River. Such dumpsites are a major source of environmental contamination as they contain highly polluted leachates that percolate into the soil and subsequently contaminate the aquifers in the sub-surface [5].

Different researchers have observed the adverse impact of leachate plumes on the soil [6,7] as well as on the surface and groundwater [8,9]. Therefore, detailed assessment of MSW dumpsites is one of the most common demands in growing urban areas which should be carried out by identifying the buried waste and delineating its geometrical dimensions, determining its geochemical characteristics (potentially toxic elements and compounds), and especially tracing the sub-surface migration pathways of leachate plumes from one medium to another within the ecosystem. For this purpose, geochemical and geophysical techniques have widely been used $[10,11]$.

Geophysical techniques have been successfully applied to study buried waste characterization and leachate plume mapping. Among geophysical techniques, electric resistivity tomography (ERT) and ground-penetrating radar (GPR) have frequently been used for the investigation of soil and groundwater contamination [12,13]. Ground-penetrating radar has been widely used to map waste deposits [14,15] and environmental pollution [16,17]. Electrical resistivity tomography also has been extensively used for contaminated site characterization [18-20] and waste characterization [21,22]. In this context, sustainable management of urban and rural environments needs continuous monitoring of solid waste and proper disposal by using geophysical and geochemical techniques.

The examination area subjected to this study was exploited for dumping domestic and commercial refuse from 2019 to early 2021. The buried waste operation on the studied dumpsite was conducted in early 2021. Time-lapse Google Earth imagery (Figure 1A,B) showed the condition of the site before and after the buried waste operation. The existing borders of the buried waste were determined by collecting information from the satellite images and questionnaire survey residents and were further confirmed through field observations. Based on field observation, the height of the dump surface relative to the surrounding terrain, the buried trash thickness, is about $3 \mathrm{~m}$. The local leachate accumulation point (Figure 1C) and some open trash deposited by the residents are adjacent to Bara River and agricultural land (Figure 1D,E). It is important to emphasize that the dumpsite is bounded by residential buildings, a cricket stadium in the west, agricultural land towards the south and east side, and Bara River towards the north (Figure 1B). The Bara River is adjacent to the dumpsite originating from the southern and western parts of the Peshawar Basin, flows towards the northeast, and finally drains to the Kabul River (Figure 3), which is irrigating the major part of the Peshawar Basin. Therefore, this area is under serious environmental contamination threat due to leachate percolation in the nearby water bodies as well as to the fertile agricultural soil. 

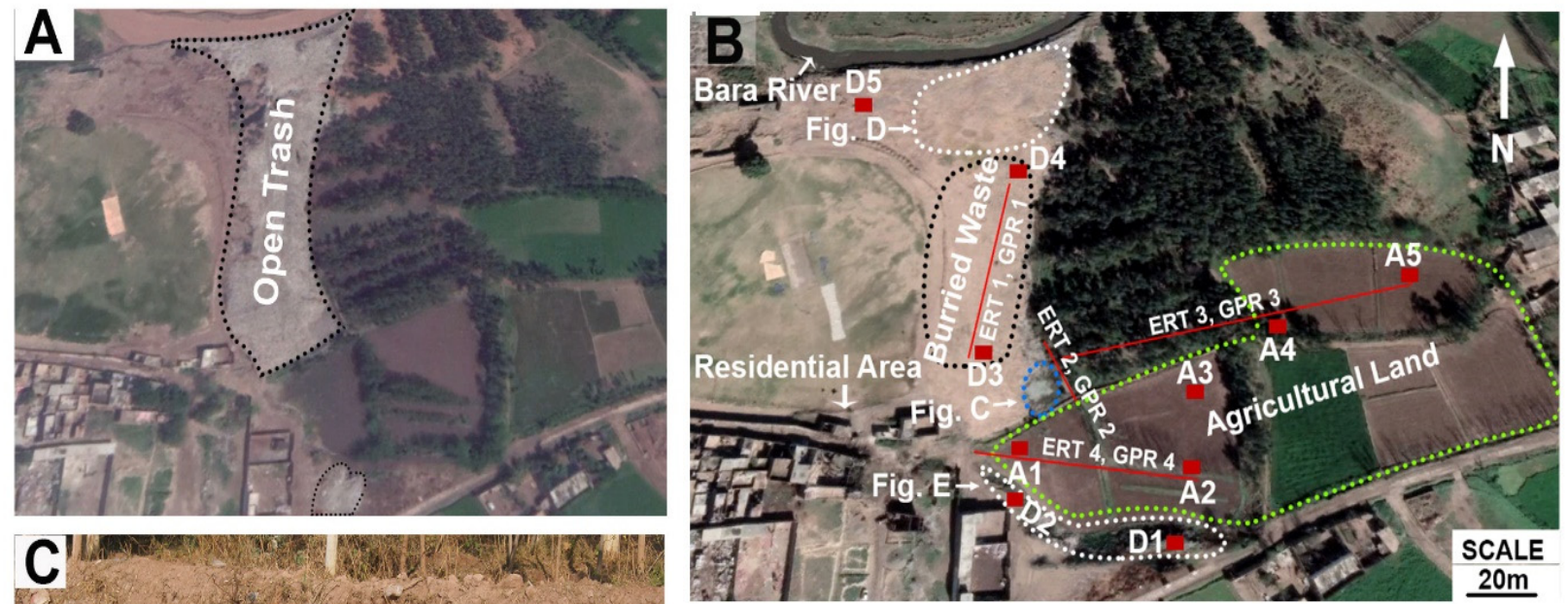

\section{Leachate Accmulation Point}

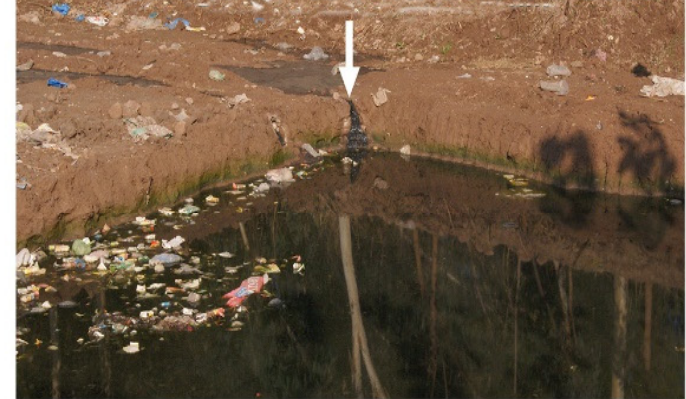

D
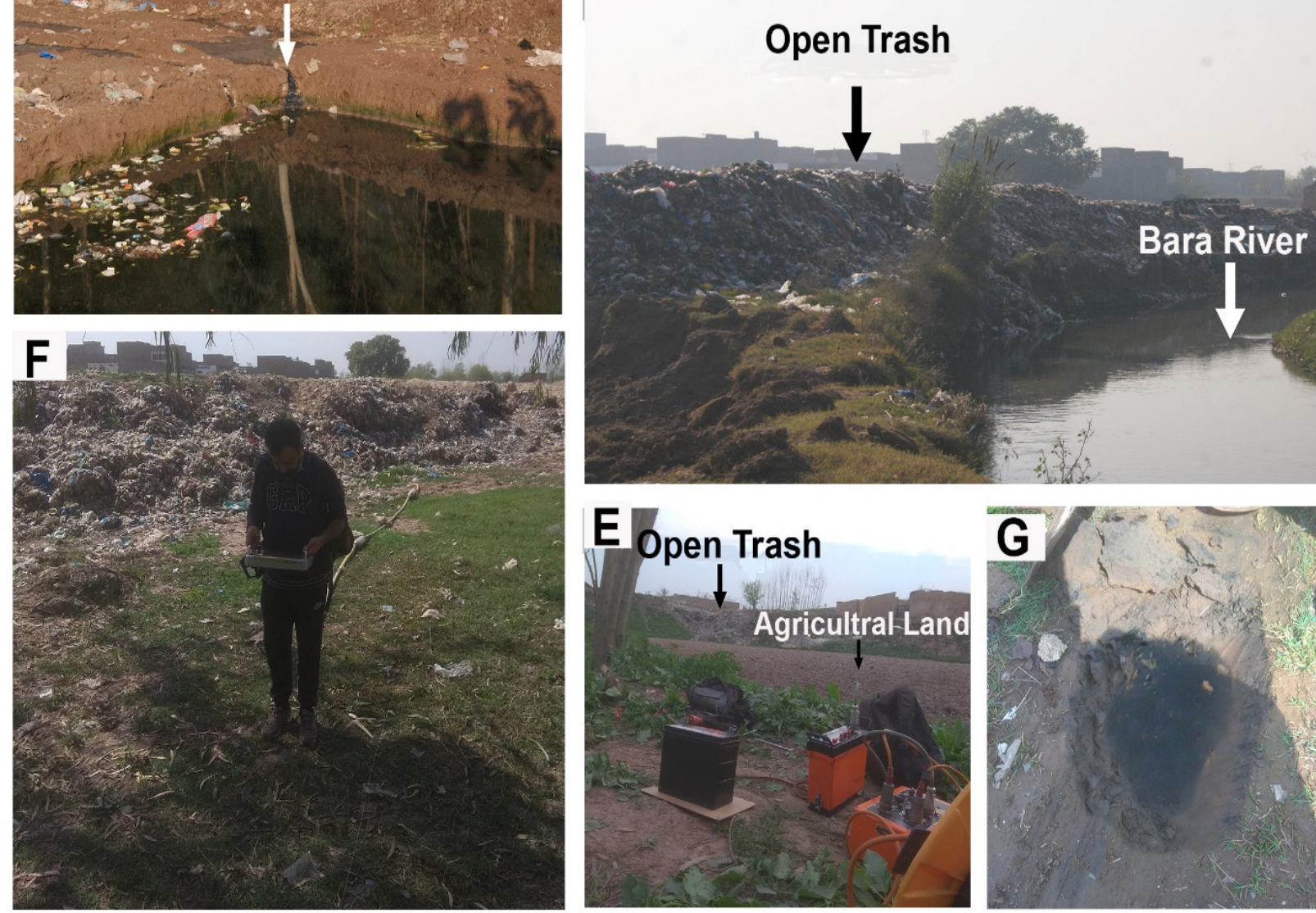

Figure 1. (A) Google Earth imagery before waste buried operation. (B) Current situation of study area after waste buried operation and profile orientation. (C) Leachate accumulation point. (D) Open trash adjacent to Bara River. (E) Open trash adjacent to agricultural land and Lund imaging system. (F) GPR data acquisition using $50 \mathrm{MHz}$ un-shielded antenna. (G) digging point along ERT-4.

The specific objectives of the present study are (1) to determine geometrical dimensions and to characterize the buried waste, (2) to map the subsurface distribution of leachate plumes towards groundwater table and agricultural land, and (3) to investigate the possibility of contamination of the nearby agricultural soil due to seepages of leachate from this dumpsite. This study directly addresses some of the Sustainable Development Goals like Goal \#3 (regarding good health) and Goal \#6 (regarding clean water and sanitation). 
This study is also designed to explore the potential harmful impacts of solid waste open dumping site on the agricultural soils and potable water resources of a big city such as Peshawar by using the geophysical as well as geochemical techniques for environmental management and sustainability.

\section{The Hydrogeological Setting of the Study Area}

The study area (Chowa Gujar), located southeast of Peshawar (33 $59^{\prime} 48.50^{\prime \prime} \mathrm{N}$, $71^{\circ} 37^{\prime} 13.91^{\prime \prime} \mathrm{E}$ ), is a part of the Peshawar Basin (Figure 2) which is an intermountain basin formed around 2.3 million years ago [23]. Peshawar Basin has been divided into four broad geological units as (1) metamorphic and igneous rocks of northern mountains, (2) the Mesozoic rocks of south and southwestern part, (3) the Tertiary rocks of central and southeastern part, and (4) Upper Tertiary and Quaternary fill of intermountain basin [24].

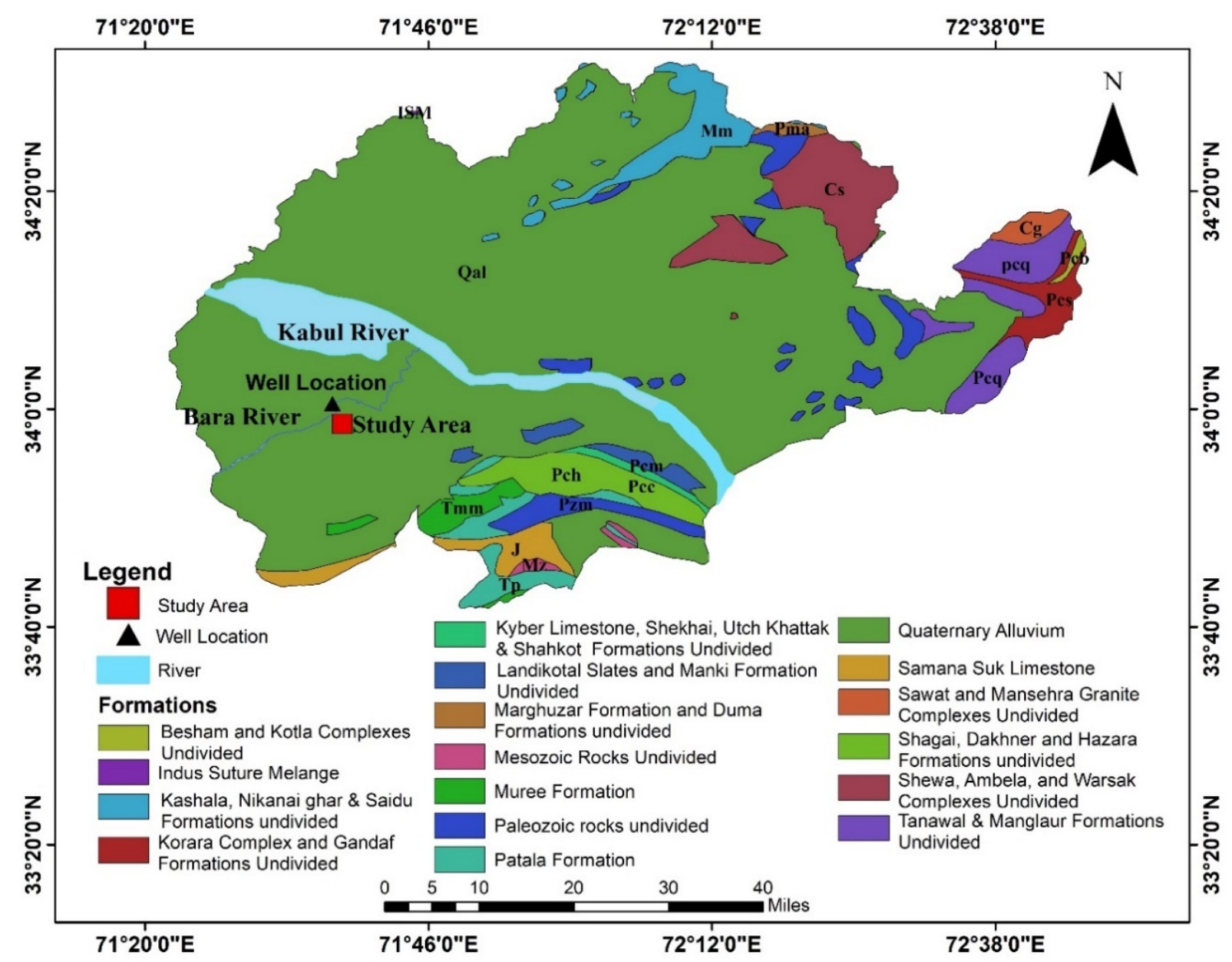

Figure 2. Geological map of Peshawar Basin, modified after Searle and Khan [25].

Peshawar Basin is surrounded by Atock-Chirat mountain ranges in the south, Swat Mountain ranges in the southeast, and Khyber mountain ranges in the northwest. A central part of the Peshawar Basin is covered with Quaternary sediments. Physiographical Quaternary deposits are classified as Flood Plain, Lacustrine, and Piedmont deposits [26]. Flood Plain deposits are probably deposited by Kabul and Indus Rivers. Piedmont deposits are observed along the foothills at the margins of Peshawar Basin. During the middle Pleistocene, Lacustrine deposits were formed, because of overflow blockage of the Indus River [27].

Hydro-geologically Peshawar Basin is classified into three types of aquifer based on main lithologies of the area such as Peshawar Piedmont, Peshawar Lacustrine, and Peshawar Flood Plain aquifers [28]. The aquifer with a groundwater level of $24 \mathrm{~m}$ is located 
down-gradient of the Chowa Gujar dumpsite. The lithological column of a borehole was drilled up to a depth of $27 \mathrm{~m}$ at a distance of about $1.2 \mathrm{~km}$ from the dumpsite, and shows a $6 \mathrm{~m}$ thick top layer of clay followed by a $3 \mathrm{~m}$ strata of gravel boulder with a very high resistivity $\log$ value. At a depth of 9-15 $\mathrm{m}$, thin lenses of clay and gravel are encountered alternatively, while at depth of $15-21 \mathrm{~m}$ sand with minor clay has been observed. At a depth of 21-27 $\mathrm{m}$ there is saturated strata gravel boulder with low resistivity log value as compared to dry strata, below which gravel sand strata is encountered (Figure 3).
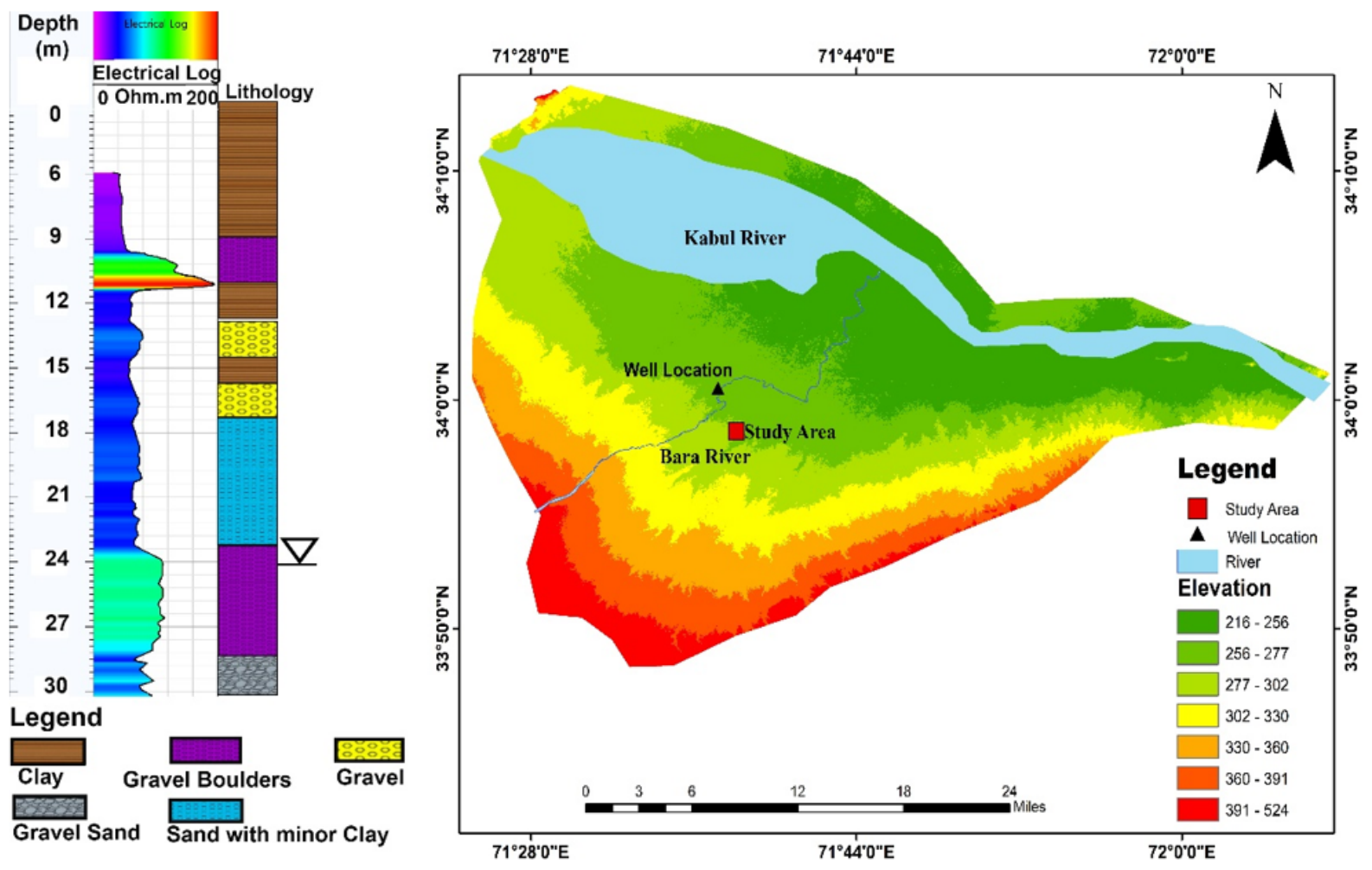

Figure 3. Borehole log obtained from a representative borehole B\#28 (at $1.2 \mathrm{~km}$ of dumpsite) and trend of elevation in the study area.

Groundwater flow is a valuable indicator for determining the flow patterns of potential contaminants in the groundwater system [29]. Therefore, the topography trend was considered an important factor during the designing of the geophysical survey. In the study area, the groundwater flow direction is from the north towards the east and from the southwest towards the eastern region [30], which is a replica of the topographic trend in the area (Figure 3).

\section{Materials and Methods}

Geophysical and geochemical techniques are useful tools for determining the geology and hydrology and geochemistry of the surface and subsurface horizons. Integration of different techniques provides a more synergistic interpretation of the sub-surface data, which frequently leads to a more accurate model of the subsurface complex structures and processes.

\subsection{Electric Resistivity Tomography}

ERT is a non-invasive geophysical technique that is employed at the ground surface by introducing an electric current into the soil, measuring the potential difference response, and then calculating the apparent electrical resistivity [31]. A high concentration of charged particles facilitates the electrolytic conduction process which enables the ERT to perform well. 
The ERT technique has widely been used in landfill investigations that involve contaminated soils and aquifers due to percolated constituents of leachate. The conductive nature of dumpsite material to the near-surface soil media and aquifers makes ERT an efficient geophysical tool in such types of studies [32].

The ERT measurements were conducted along with four profiles (ERT-1 to ERT-4) with $1 \mathrm{~m}$ and $2 \mathrm{~m}$ electrode spacing depending on the available space. The details of ERT profiles positions and acquisition parameters are given in Figure 1B and Table 1 respectively. Wenner-Schlumberger configuration was adopted by different researchers to estimate the depth of buried waste and map contaminant plumes, because of its high signal to noise ratio, sensitivity to both horizontal and vertical changes, and good penetration depth $[10,21,33]$. The RES2DINV software was used for data processing. The ERT data were inverted based on a least-squares algorithm to obtain a two-dimensional distribution model [34].

Table 1. Acquisition parameters of the ERT survey.

\begin{tabular}{ccccc}
\hline Profile Name & ERT-1 & ERT-2 & ERT-3 & ERT-4 \\
\hline Length $(\mathrm{m})$ & 80 & 40 & 160 & 80 \\
\hline $\begin{array}{c}\text { Electrode } \\
\text { Spacing }(\mathrm{m})\end{array}$ & 1 & 1 & 2 & 1 \\
\hline Survey Type & Long & Short & Long & Long \\
\hline
\end{tabular}

The resistivity raw data were mostly analyzed for five iterations because they reveal a more logical subsurface geological model with less root mean square (RMS) error. For a fair analogy, the color scale for all inversion models is the same.

\subsection{Ground Penetrating Radar (GPR)}

Ground Penetrating Radar emits high-frequency electromagnetic waves ( $1 \mathrm{MHz}$ to $1000 \mathrm{MHz}$ ) [35]. GPR method has been applied to a variety of problems such as detection of voids in the subsurface and geological layer boundaries, location of installations, and archaeological and forensics studies [36,37]. The GPR applications to monitor landfill have been discussed by [38]. For better interpretation, it is usually used with the integration of electrical methods [39].

In the present study, GPR data were acquired in continuous mode MALA GPR system equipped with $50 \mathrm{MHz}$ frequency un-shielded antenna. The acquisition parameters (time window, sampling frequency) were selected according to the type of antenna and site conditions. Time window was selected $30 \mathrm{~ns}$, sampling frequency was set at $500 \mathrm{MHz}$ (ten times the antenna frequency).

A REFLEXW program [40] was used to process the data. Different processing schemes were applied to improve the quality of results. For instance, to remove the effect of time misalignment and ringing effect, static correction and background filter were applied to the data. To intensify the amplitude linear and exponential gain functions were applied. In the last step subsurface velocity of $0.2 \mathrm{~m} / \mathrm{ns}$ was acquired via the hyperbolae overlap method and used for time to depth conversion.

\subsection{Sample Collection and Geochemical Analysis}

Soil samples were collected randomly from the dumpsite and the nearby agricultural land. Five representative soil samples were collected from $(0-20 \mathrm{~cm})$ open and buried dump waste site while five samples were collected from adjacent agricultural land and five samples were collected from referenced area. These soil samples were collected according to the United States Environmental Protection Agency soil sampling protocols [41].

The organic matters from the soil samples were hand-picked and then sieved to 2-mm mesh. These were then pulverized in the vibrating disc mill. About $1 \mathrm{~g}$ of each powdered sample was placed in the Teflon beakers, $10 \mathrm{~mL}$ of hydrofluoric acid (HF) of analytical grade was added and heated on a hot plate in a fume hood. After heating for a while, $20 \mathrm{~mL}$ 
of aqua regia $\left(3 \mathrm{HCL} / 1 \mathrm{HNO}_{3}\right)$ of analytical grade was added and kept on heat. After complete dryness, then $20 \mathrm{~mL} \mathrm{HCL}(2 \mathrm{~N})$ was added and heated for a while and then the digested contents were filtered and diluted up to $50 \mathrm{~mL}$. All the treated samples were then transferred in clean polythene bottles for further analysis. Final solutions were analyzed through an atomic absorption spectrometer (Perkin Elmer AA700) under standardized conditions.

\subsection{Geo-Accumulation Index}

The geogenic or anthropogenic accumulated pollution loads in soil are measured using the geo-accumulation index and have been calculated using the formula below.

$$
I_{\text {geo }}=\log _{2}\left(\frac{C_{n}}{1.5 * B_{n}}\right)
$$

where $C_{n}$ is a concentration of metals in the target area and $B_{n}$ is the concentration of metals in referenced area. The factor 1.5 is used to account for the possible variations in the referenced area values.

\subsection{Enrichment Factor}

The enrichment factor $(E F)$ was determined for the level of elements enrichment in soil It can be calculated through the following formula [42]:

$$
E F=\left(\frac{C_{n}}{C_{m}}\right) \div\left(\frac{C_{b}}{C_{x}}\right)
$$

where $C_{n}$ is the element concentration in the target area, $C_{m}$ is the lowest possible concentration in the target area of an element, $C_{b}$ is the element concentration in the referenced area, and $C_{x}$ is the lowest possible concentration of an element in the reference area.

\section{Results and Discussion}

\subsection{Waste Characterization and Leachate Plumes Mapping Using ERT and GPR Imaging}

Profile ERT-1 was acquired on the surface of the dumpsite to determine the extent of waste deposit and to detect sub-surface pathways of a plume. The inverted model (Figure 4A) shows the waste-contained zone along with ERT-1 profile from 0 to $40 \mathrm{~m}$ characterized by $31 \Omega \mathrm{m}$ to $50 \Omega \mathrm{m}$ resistivity value within upper $4 \mathrm{~m}$. Further $40 \mathrm{~m}$ to $60 \mathrm{~m}$ zone with resistivity value of $25 \Omega \mathrm{m}$ within $\sim 1 \mathrm{~m}$ is defined as natural ground. However, a homogenous resistivity zone having values about 50 to $80 \Omega \mathrm{m}$ is observed underneath the natural ground may be indicating old or less saturated domestic waste material marked by a black dotted line. Another waste-contained cell is observed in the N-E part of ERT-1 with a very high resistivity of about 80 to $125 \Omega$ m extended a few meters below the ground surface. An important anomalous zone characterized by extremely low resistivity $\leq 8 \Omega \mathrm{m}$ is observed at depth of $\sim 6 \mathrm{~m}$. This zone is interpreted as contaminant plumes, and it is extended up to $14 \mathrm{~m}$ in the sub-surface. The NE dipping anomaly and trend of elevation (Figure 3) indicate that the plumes have their origin in the SW portion of ERT-1 and may probably migrate in the NE direction over time in the future. The zone between waste contained zone and leachate plumes is known as the intermittent zone, which is observed between the depth of $4 \mathrm{~m}$ to $6 \mathrm{~m}$ and is the lower limit of solid dump waste and a transition to a high conductive zone. 


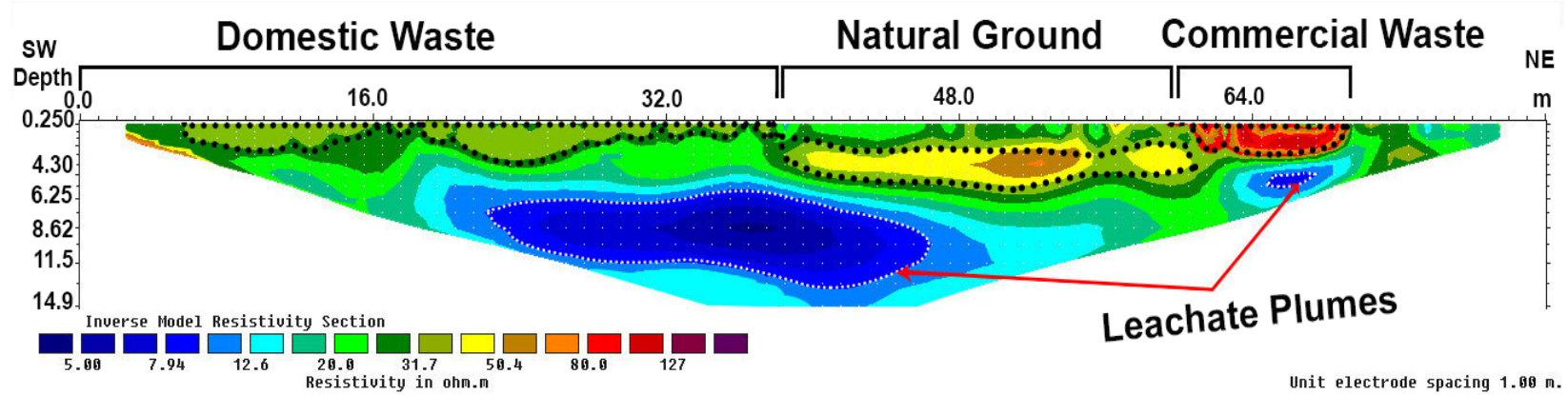

(A)

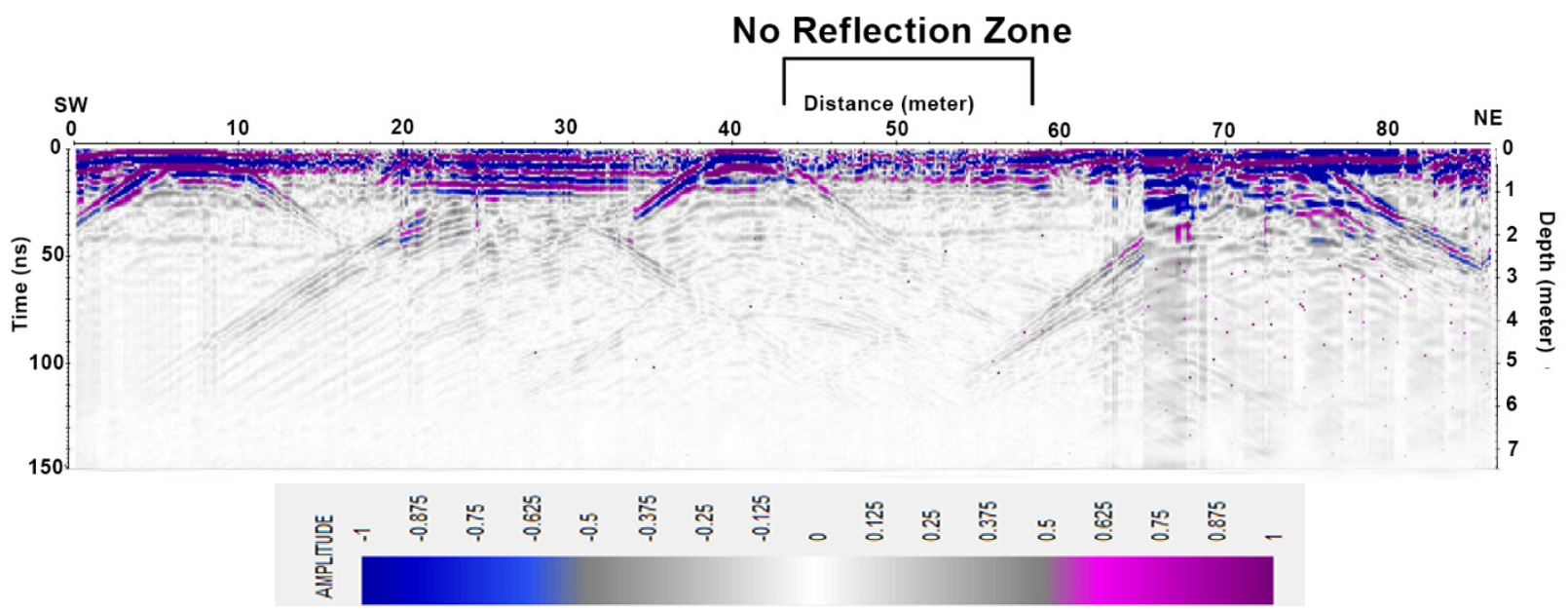

(B)

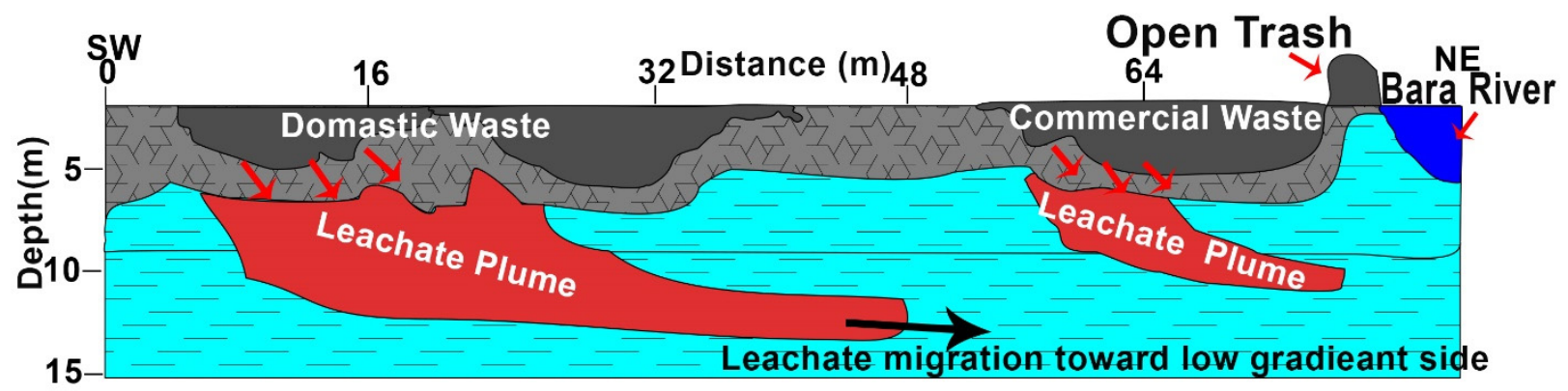

(C)

Figure 4. (A) Inverted resistivity section along ERT-1. (B) Processed GPR section along GPR-1. (C) Subsurface cross-section based on ERT-1 and GPR-1 sections.

GPR section (Figure 4B) reveals the continuous reflections on the top relating to the surface cover. The very near-surface of dumpsite was not imaged based on radar reflections except the boundaries of different zones (domestic waste, old buried or less saturated domestic waste and commercial waste) compared to ERT-1 which helped in distinguishing several features within this depth. There are substantial reflections within the top $4 \mathrm{~m}$ and laterally these strong reflections are prominent between 0 to $40 \mathrm{~m}$ and then 60 to $80 \mathrm{~m}$. Furthermore, ref. [14] indicated that dumpsite produce discontinuous intense scattering regions on radargram. According to [43] strong diffraction hyperbola is produced because of the high reflectivity of buried waste and the high heterogeneity of buried waste disturb the soil media. The strong signals at different depths underneath those areas covered by 
domestic and commercial wastes are attributed to the targets (rubbles and metallic wastes) within a waste deposit.

Sub-surface section ERT-1 (Figure 4A) and GPR-1 (Figure 4B) have a favorable correlation in defining the thickness of the waste-containing zone as well as characterization of the waste. The studied dump thickness is about $4 \mathrm{~m}$, below which resistivity value drop less than $8 \Omega \mathrm{m}$ and serious radar signal attenuation is observed, that is probably related to plumes of conductive leachate. The $0-40 \mathrm{~m}$ zone can be referred to as domestic waste with resistivity range 31 to $50 \Omega \mathrm{m}$ and some prominent GPR reflections are observed up to the depth of $4 \mathrm{~m}$. No significant reflection is observed on the top section, $\sim 1 \mathrm{~m}$ of radargram between 40 to $60 \mathrm{~m}$, which can be referred to as natural ground while below this depth GPR reflection is observed can be referred to as old buried domestic waste or less saturated domestic waste with resistivity range of 50 to $80 \Omega \mathrm{m}$. Between 60 to $75 \mathrm{~m}$ zone concentration of GPR signal reflections is high as compared to 0 to $60 \mathrm{~m}$ zone of the radargram and high resistivity values 80 to $127 \Omega \mathrm{m}$ are also observed exactly in this zone, suggesting that this waste cell is filled with some commercial waste. Classification of waste based on resistivity variation and the maximum depth of each waste-contained zone is mentioned in Table 2.

Table 2. Classification of dumpsite waste.

\begin{tabular}{cccc}
\hline Waste Type & Resistivity Range $\mathbf{( \Omega \mathbf { m } )}$ & $\begin{array}{c}\text { Location along the } \\
\text { Profile }(\mathbf{m})\end{array}$ & Thickness (m) \\
\hline Domestic waste & 31 to 50 & $0-40$ & 4 \\
\hline Old domestic waste & 50 to 80 & $40-60$ & $\sim 4$ \\
\hline Commercial waste & 80 to 127 & $60-75$ & 2 \\
\hline Leachate Plume & $<8$ & $21-48$ and $65-70$ & 14.9 and 7 \\
\hline
\end{tabular}

The subsurface cross-section (Figure $4 \mathrm{C}$ ) depicts the movement of the leachate plume toward the low gradient side of the study area.

Following the leachate accumulation point on the surface of low land adjacent to a dumpsite boundary profile, ERT-2 was acquired. The purpose of this profile was to see the leachate concentration on the very near surface. This section (Figure 5A) is located close to the leachate accumulation point and the depth of leachate percolation is very shallow, $\sim 2 \mathrm{~m}$ as compared to ERT-1 (Figure 4A). The near-surface resistivity of this section is $<5 \Omega \mathrm{m}$ (white dotted line) lower than the ERT-1. Therefore, it can be concluded that the leachate mineralization is high at the shallow depth close to the leachate accumulation point as compared to the leachate of the waste-containing zone. Below the leachate saturated zone between the depth of 2-5 m, there are dry strata of gravel. Similar very low resistivity patterns have been reported for leachate saturated zones in a controlled environment $[44,45]$.

GPR-2 (Figure 5B) reveals that at the top of radargram signal attenuated significantly. High conductive nature of leachate plume is assumed to be responsible for severe attenuation. GPR signal dies out as it interacts with a highly conductive contaminated body, therefore no reflection is observed below the signal attenuation zone [46]. A similar pattern of subsurface contamination generated by dumpsites was also observed by $[37,47,48]$. In the current study, some diffraction signals are observed towards the agricultural landside, which could be due to uncontaminated land. 


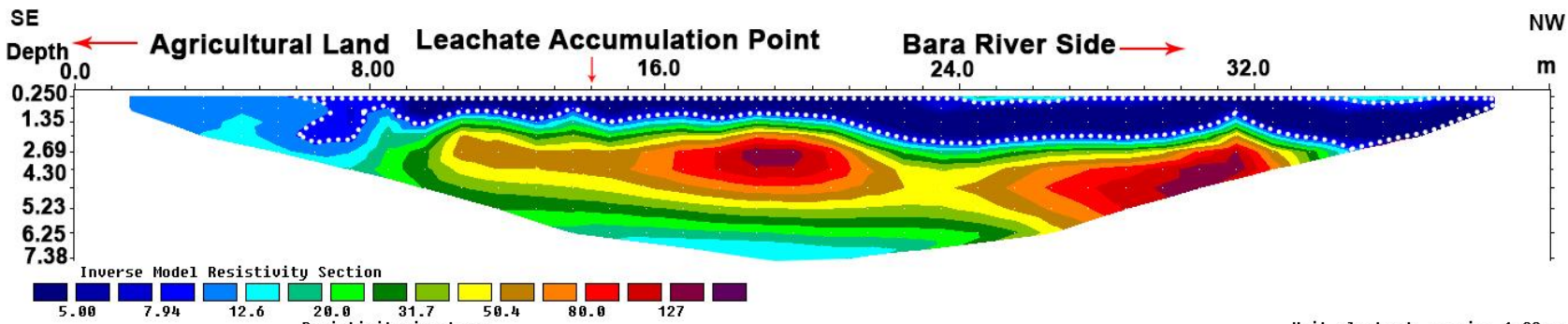

(A)

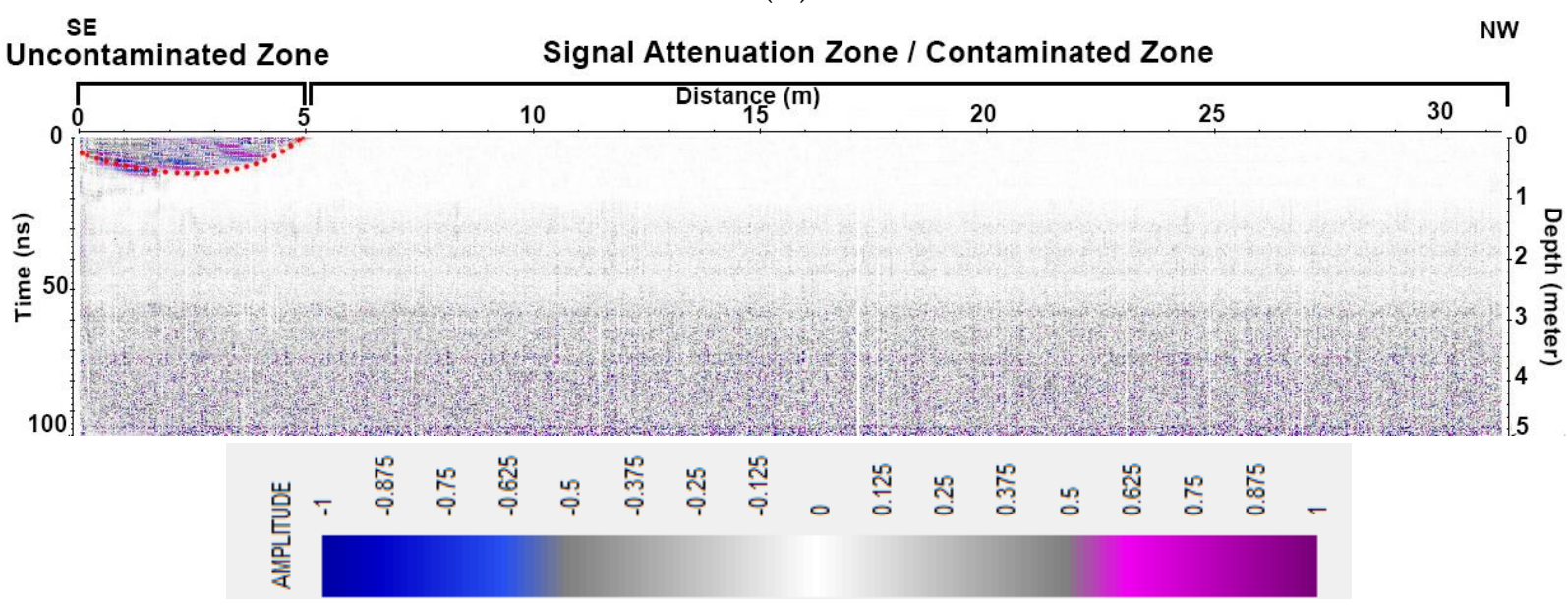

(B)

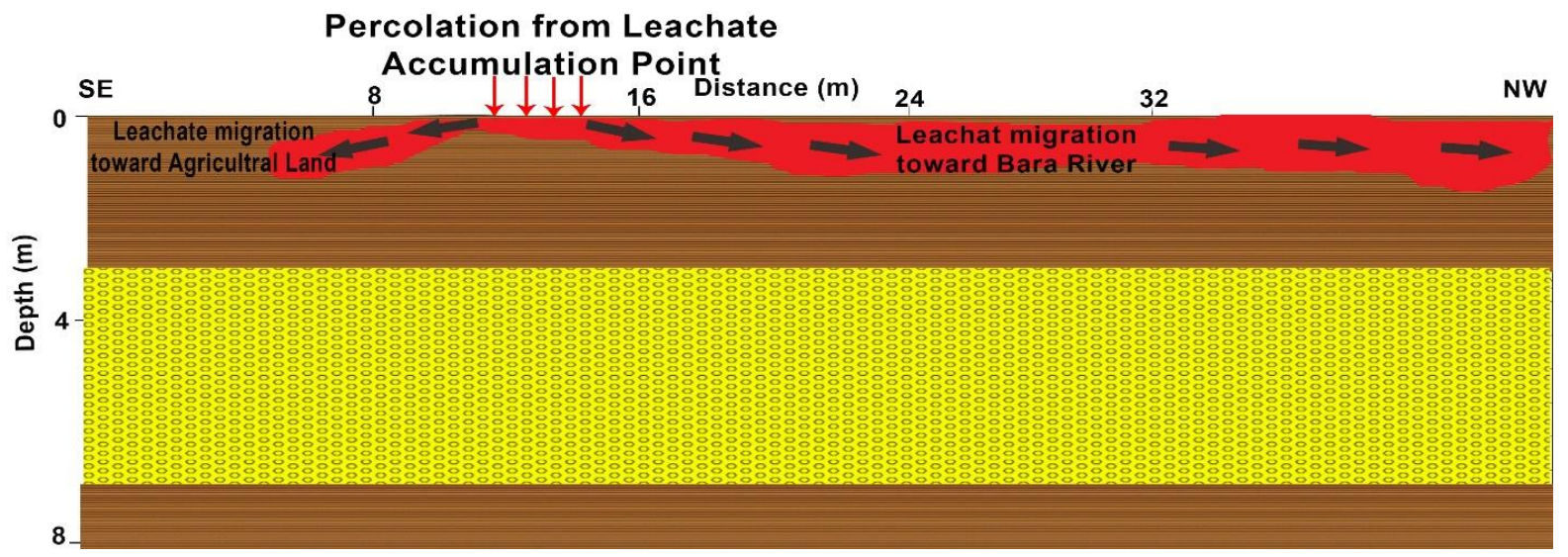

(C)

Figure 5. (A) Inverted resistivity section along ERT-2. (B) Processed GPR section along GPR-2. (C) Subsurface cross-section based on ERT-2 and GPR-2 sections.

Subsurface cross-section based on ERT-2 and GPR-2 sections (Figure 5C) revealed that the concentration of leachate plumes from the accumulation point is high towards the Bara Riverside as compared to the agricultural land.

Profile ERT-3 was acquired from leachate accumulation point towards agricultural land on the eastern side. The purpose of this profile was to map the spatial and vertical distribution of plumes and to delineate the potential leachate migration routes beyond the leachate accumulation point toward agricultural land. The physical distance between the leachate accumulation point and agricultural land is $80 \mathrm{~m}$. ERT-3 section (Figure 6A) reveals that the low resistivity zone $(<5 \Omega \mathrm{m})$ marked by a dotted white line is extended up to $110 \mathrm{~m}$ laterally and $8 \mathrm{~m}$ vertically. Below the low resistivity zone from $8 \mathrm{~m}$ to $28 \mathrm{~m}$ there are thick strata of $20 \mathrm{~m}$. Based on borehole data this zone is interpreted as saturated gravel boulder strata with resistivity value $(>80 \Omega \mathrm{m})$. 
W

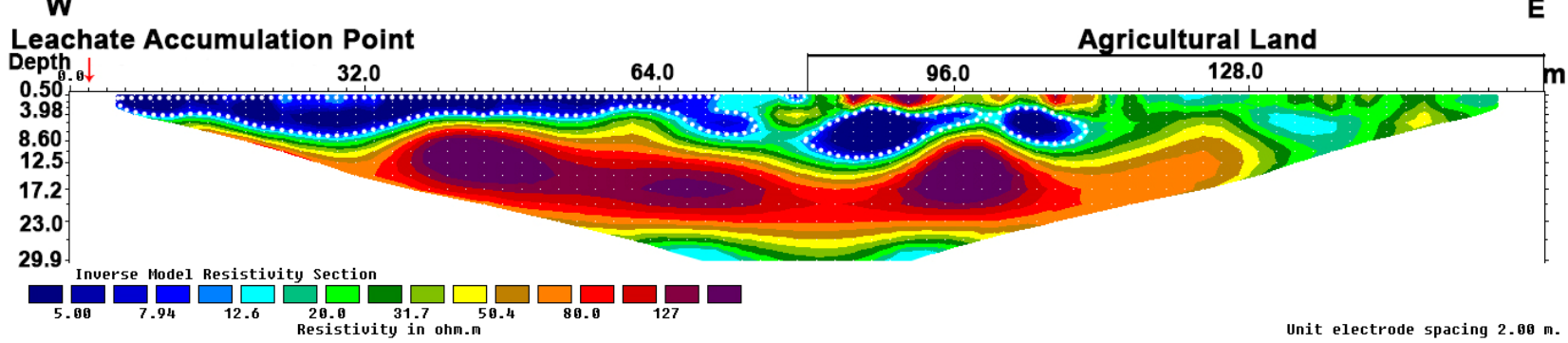

(A)

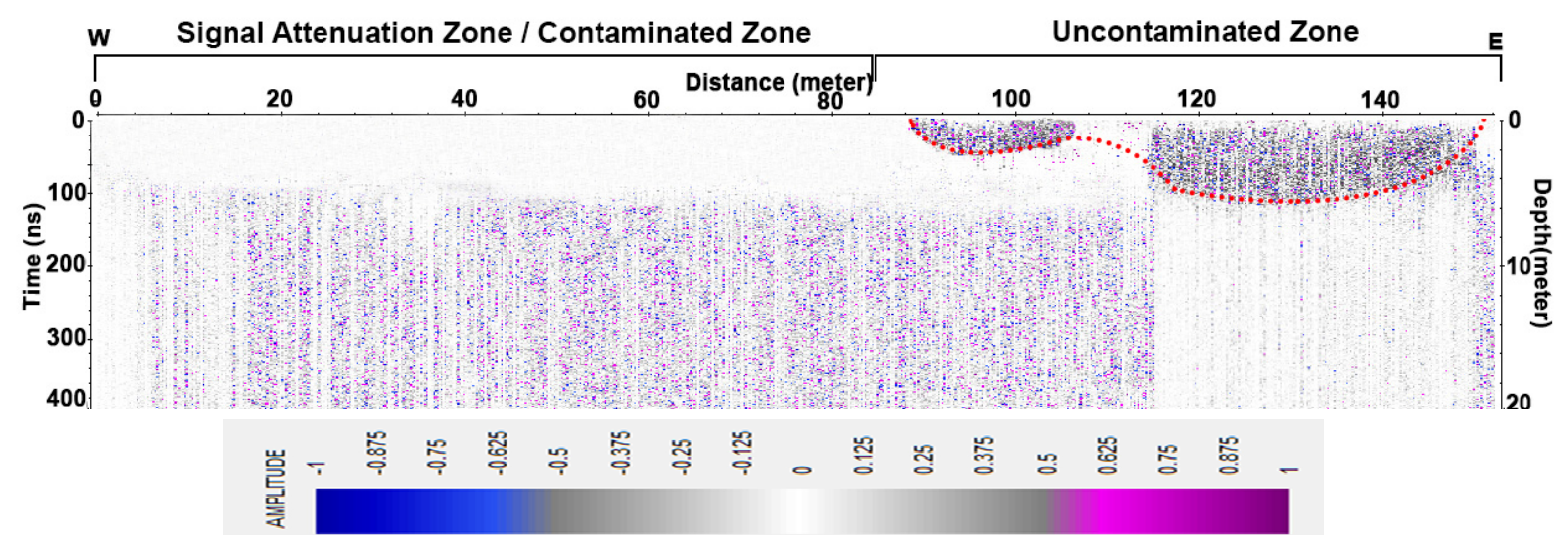

(B)

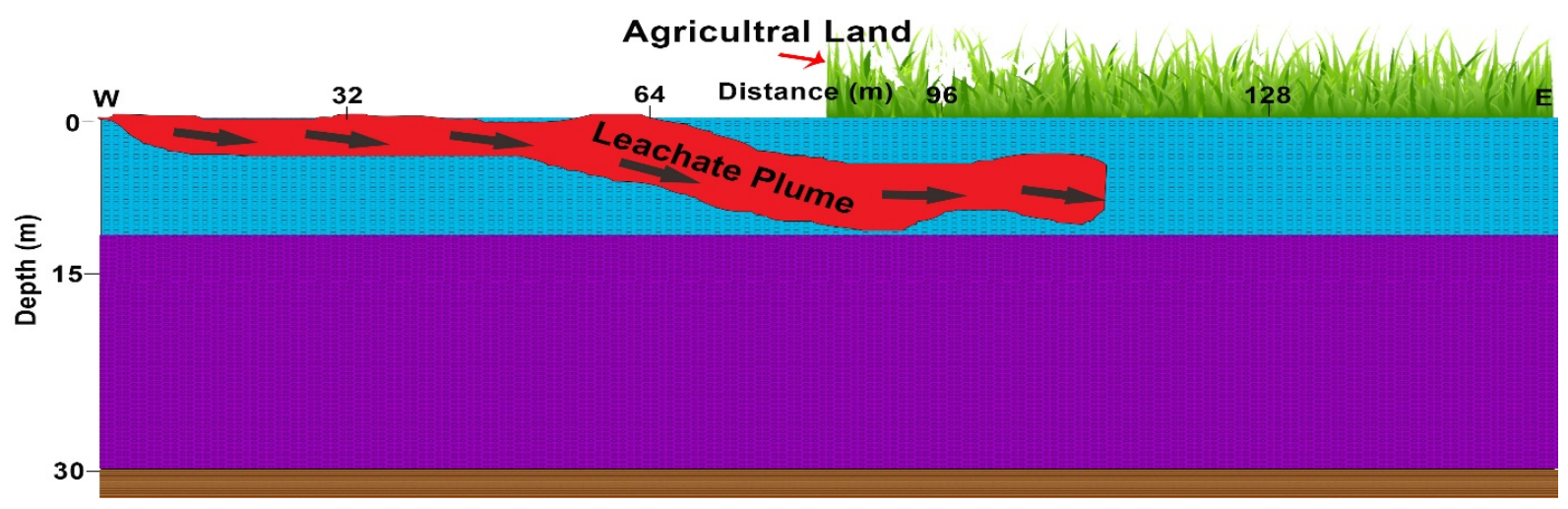

(C)

Figure 6. (A) Inverted resistivity section along ERT-3. (B) Processed GPR section along GPR-3. (C) Subsurface cross-section based on ERT-3 and GPR-3 sections.

Profile GPR-3 was about $160 \mathrm{~m}$ long and the location of a profile is the same as the location of ERT-3. The signal attenuation is observed from 0 to $90 \mathrm{~m}$ on radargram while the diffraction signal is observed between the distance of 90 to $104 \mathrm{~m}$, which could be related to the near-surface abnormalities or uncontaminated geological strata which can also be correlated with the ERT-3 section (Figure 6A). Signal attenuation from 104 to $114 \mathrm{~m}$ along GPR-3 is observed which could be due to a leachate lens that is consistent with the very low conductive zone of the ERT-3 section.

Subsurface cross-section based on ERT-3 and GPR-3 (Figure 6A,B) depicts leachate plumes that have penetrated up to $8 \mathrm{~m}$ with a lateral extension of about $30 \mathrm{~m}$ within the agricultural land and it has not yet reached the groundwater table.

Profile ERT-4 was acquired within agricultural land adjacent to open dump waste. Section ERT-4 (Figure 7A) depicts that a low resistivity anomalous zone is observed between $12 \mathrm{~m}$ and $55 \mathrm{~m}$ laterally with a vertical extension of more than $14 \mathrm{~m}$. The low resistivity 
anomalous zone is interpreted as leachate concentrated area in the shallow sub-surface, which is the reason for the attenuation in the upper section of the radargram (Figure 7B). Radar reflections are observed at the start and end of the radargram due to uncontaminated land. The source of contamination along these profiles could be the adjacent open dump waste. GPR and ERT results demonstrate that open dumpsite has resulted in polluting the agricultural land and may hit the shallow groundwater table in the future.

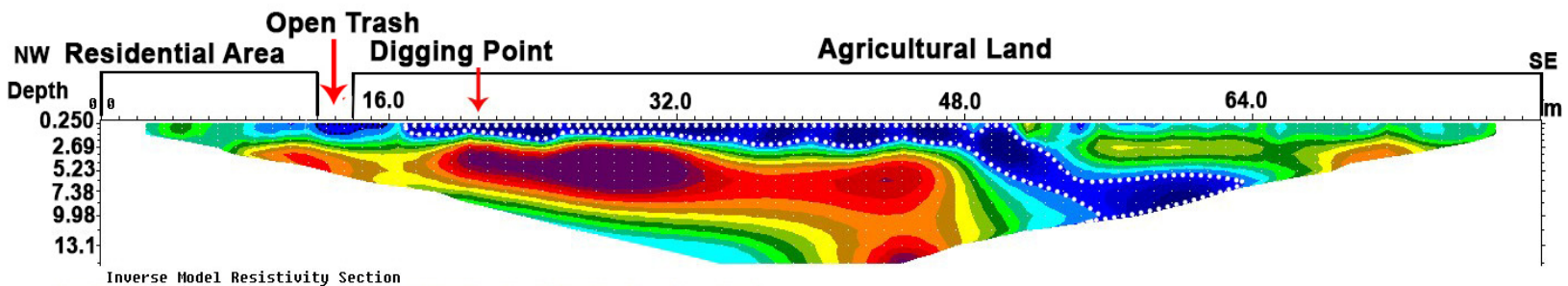

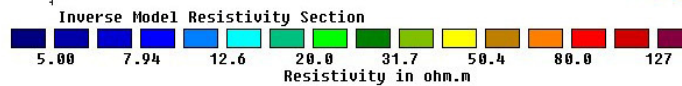

Unit electrode spacing 1.80 $\mathrm{m}$.

(A)

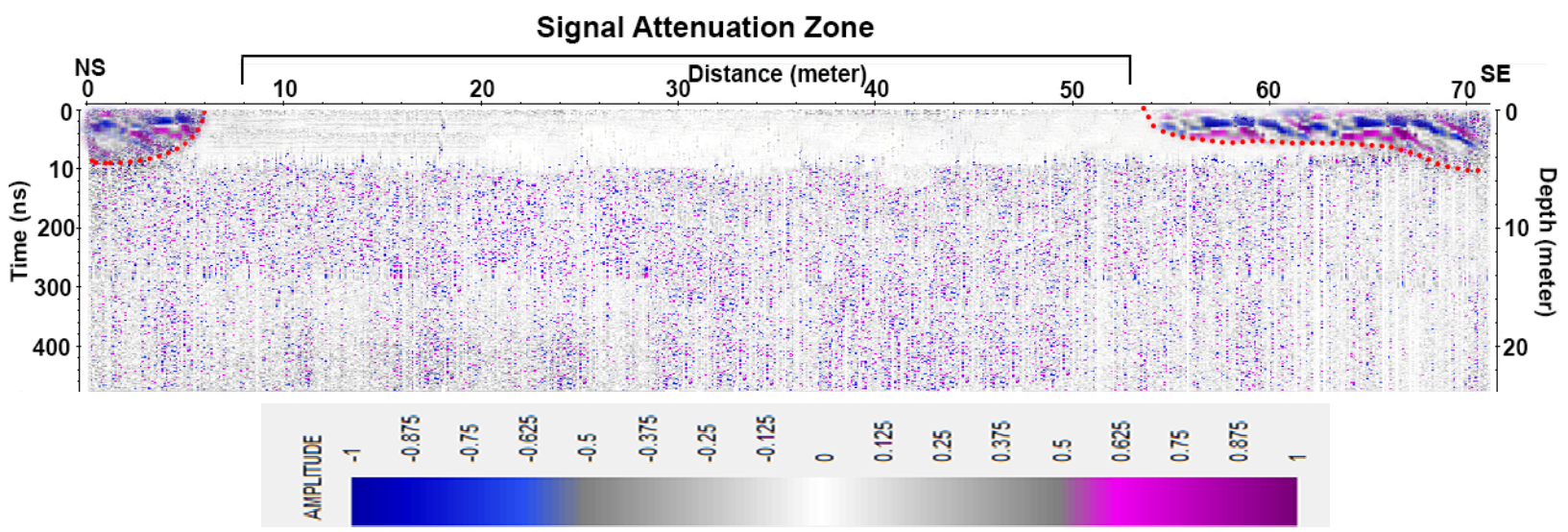

(B)

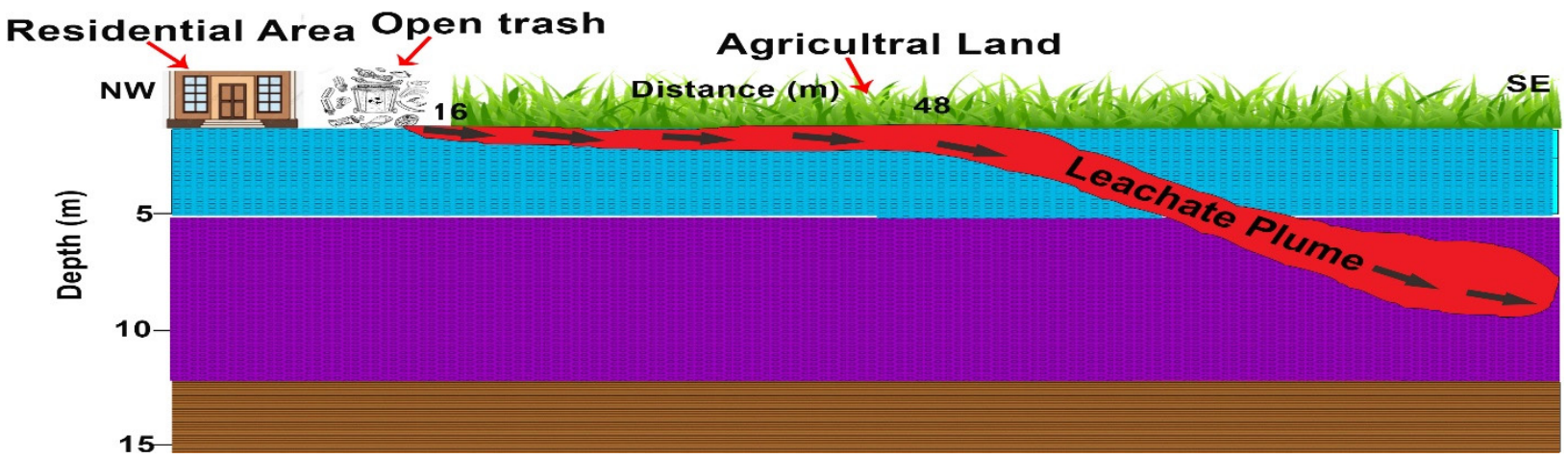

(C)

Figure 7. (A) Inverted resistivity section along ERT-4. (B) Processed GPR section along GPR-4. (C) Subsurface cross-section based on ERT-4 and GPR-4 sections.

To validate the near-surface saturation of leachate, a small portion of survey line ERT-4 and GPR-4 was dug out up to a depth of $0.5 \mathrm{~cm}$ for visual observation (Figure 1G).

Based on resistivity sections and borehole data, a specific range of resistivity for different lithology and leachate plume in the study area is given in Table 3: 
Table 3. Resistivity and lithology calibration.

\begin{tabular}{cc}
\hline Resistivity $(\Omega \mathbf{m})$ & Lithology \\
\hline$<8$ & Leachate \\
$8-12$ & Clay \\
$12-31$ & Sand with minor clay \\
$31-51$ & Gravel \& sand \\
$51-80$ & Gravel \\
$>80$ & Gravel and bolder \\
\hline
\end{tabular}

\subsection{Soil Contamination}

Tables 4 and 5 exhibit the basic descriptive statistical values of heavy metals (HMs) concentration of dumpsite soil and adjacent agricultural land. In solid waste dump soil mean concentrations of $\mathrm{Cr}, \mathrm{Cd}, \mathrm{Pb}, \mathrm{Ni}, \mathrm{Cu}, \mathrm{Zn}$, and $\mathrm{Co}$ are $28.5 \mathrm{mg} / \mathrm{kg}, 6.16 \mathrm{mg} / \mathrm{kg}, 17.58 \mathrm{mg} / \mathrm{kg}$, $46.08 \mathrm{mg} / \mathrm{kg}$, $115.79 \mathrm{mg} / \mathrm{kg}, 83.37 \mathrm{mg} / \mathrm{kg}$, and $27.72 \mathrm{mg} / \mathrm{kg}$, respectively, while the mean concentrations of these heavy metals in the agriculture land are $23.72 \mathrm{mg} / \mathrm{kg}, 4.18 \mathrm{mg} / \mathrm{kg}$, $10.57 \mathrm{mg} / \mathrm{kg}, 24.37 \mathrm{mg} / \mathrm{kg}, 45.58 \mathrm{mg} / \mathrm{kg}, 55.09 \mathrm{mg} / \mathrm{kg}$, and $18.81 \mathrm{mg} / \mathrm{kg}$, respectively. The trend of heavy metals in dump soil appears as $\mathrm{Cu}>\mathrm{Zn}>\mathrm{Ni}>\mathrm{Co}>\mathrm{Cr}>\mathrm{Pb}>\mathrm{Cd}$ and in agricultural soil as $\mathrm{Zn}>\mathrm{Cu}>\mathrm{Ni}>\mathrm{Cr}>\mathrm{Co}>\mathrm{Pb}>\mathrm{Cd}$. In the case of land use type, the concentration of heavy metals (HMs) in dump soil is greater than that of agricultural soil (Figure 8). However, the concentration of all the HMs in the target area was found higher than that of the reference area.

Table 4. Heavy metals concentration $(\mathrm{mg} / \mathrm{kg})$ in dump site.

\begin{tabular}{ccccccccc}
\hline Land Use & $\begin{array}{c}\text { Heavy } \\
\text { Metals }\end{array}$ & $\begin{array}{c}\text { Minimum } \\
\mathbf{m g} / \mathbf{k g}\end{array}$ & $\begin{array}{c}\text { Maximum } \\
\mathbf{m g} / \mathbf{k g}\end{array}$ & $\begin{array}{c}\text { Mean } \\
\mathbf{m g} / \mathbf{k g}\end{array}$ & $\begin{array}{c}\text { Standard } \\
\text { Deviation }\end{array}$ & $\begin{array}{c}\text { Mean } \\
\text { Reference } \\
\text { Value }\end{array}$ & $\begin{array}{c}\text { CCME, } \\
\mathbf{2 0 0 7} \mathbf{~ m g / k g}\end{array}$ & $\begin{array}{c}\text { CEPA, 1995 } \\
\mathbf{m g} / \mathbf{k g}\end{array}$ \\
\hline & $\mathrm{Cr}$ & 26.45 & 30.7 & 28.5 & 1.61 & 18 & 64 & 200 \\
& $\mathrm{Cd}$ & 4.55 & 10.85 & 6.16 & 1.19 & 0.52 & 10 & 0.60 \\
Dump Site & $\mathrm{Pb}$ & 7.5 & 26.4 & 17.58 & 8.19 & 2.45 & 140 & 300 \\
& $\mathrm{Ni}$ & 37.4 & 66.8 & 46.08 & 14.54 & 2.50 & 50 & 63 \\
& $\mathrm{Cu}$ & 43.2 & 336.4 & 115.79 & 26.92 & 18 & 200 \\
& $\mathrm{Zn}$ & 42.5 & 176 & 83.37 & 54.29 & 45.65 & 200 & 250 \\
& $\mathrm{Co}$ & 19.4 & 44.4 & 27.7 & 9.79 & 12 & 50 & N/A \\
\hline
\end{tabular}

Table 5. Heavy metals concentration $(\mathrm{mg} / \mathrm{kg})$ mean values in agricultural soil.

\begin{tabular}{|c|c|c|c|c|c|c|c|c|}
\hline Land Use & $\begin{array}{l}\text { Heavy } \\
\text { Metals }\end{array}$ & $\begin{array}{l}\text { Minimum } \\
\mathrm{mg} / \mathrm{kg}\end{array}$ & $\begin{array}{c}\text { Maximum } \\
\mathrm{mg} / \mathrm{kg}\end{array}$ & $\begin{array}{l}\text { Mean } \\
\text { mg/kg }\end{array}$ & $\begin{array}{l}\text { Standard } \\
\text { Deviation }\end{array}$ & $\begin{array}{c}\text { Mean } \\
\text { Reference } \\
\text { Value }\end{array}$ & $\begin{array}{c}\text { CCME, } \\
2007 \mathrm{mg} / \mathrm{kg}\end{array}$ & CEPA, 1995 \\
\hline \multirow{7}{*}{$\begin{array}{l}\text { Agricultural } \\
\text { Land }\end{array}$} & $\mathrm{Cr}$ & 20.5 & 26.6 & 23.72 & 2.72 & 18 & 64 & 200 \\
\hline & $\mathrm{Cd}$ & 2.6 & 5.7 & 4.18 & 1.11 & 0.52 & 1.4 & 0.6 \\
\hline & $\mathrm{Pb}$ & 0.35 & 21.25 & 10.57 & 9.49 & 0.45 & 70 & 300 \\
\hline & $\mathrm{Ni}$ & 2.5 & 53.05 & 24.37 & 21.15 & 2 & 50 & 50 \\
\hline & $\mathrm{Cu}$ & 29 & 68.3 & 45.58 & 16.18 & 18 & 63 & 200 \\
\hline & $\mathrm{Zn}$ & 45.65 & 77.05 & 55.09 & 12.72 & 46 & 200 & 250 \\
\hline & Co & 13.85 & 23.2 & 18.81 & 3.46 & 14 & 40 & $\mathrm{~N} / \mathrm{A}$ \\
\hline
\end{tabular}



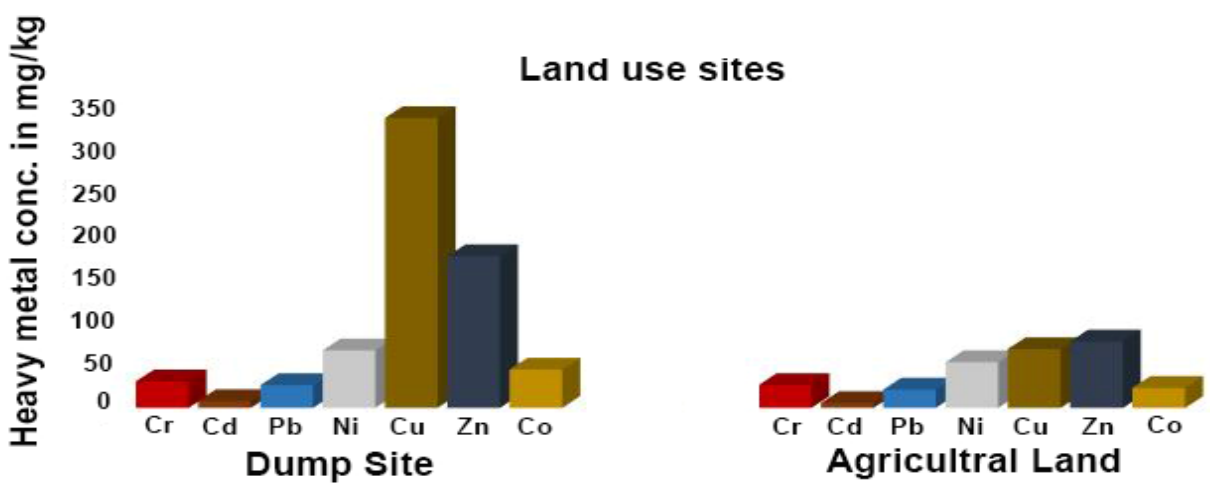

Figure 8. Heavy metal concentration $(\mathrm{mg} / \mathrm{kg})$ comparison between dumpsite and agricultural land.

The HMs concentrations were compared with the Soil Environmental Quality Standard (SEQS) such as Canadian Council of Ministers of Environment (CCME, 2007) [49], and Chinese Environmental Protection Agency (CEPA, 1995) [50], whereby Cd, Ni, and Cu concentration in the samples from dumpsite and agricultural site exceeded the quality standards of CCME, 2007 and CEPA, 1995 while the concentration of $\mathrm{Cr}, \mathrm{Co}, \mathrm{Pb}$, and $\mathrm{Zn}$ in the soils of both the sites was found to be below the soil quality criteria of CCME, 2007 and CEPA, 1995. These results show that the soil has been contaminated with heavy metals as a result of leachate migration through unfenced and unlined waste dumpsite.

The geo accumulation index of HMs in the study area is given in Table 6. According to [51], geo accumulation index values are classified as G-0 $(0<$ Igeo $\leq 1)$ unpolluted, G-1 $(1<$ Igeo $\leq 2)$ as slightly polluted, G-2 $(2<$ Igeo $\leq 3)$ as moderately polluted, G-3 $(3<$ Igeo $\leq 4)$ as moderate to severely polluted, G-4 $(4<$ Igeo $\leq 5)$ as severely polluted, and G-5 (Igeo > 5) as severe to extremely polluted. The trend of mean Igeo index in the study area was $\mathrm{Ni}>\mathrm{Pb}>\mathrm{Cd}>\mathrm{Cu}>\mathrm{Co}>\mathrm{Zn}>\mathrm{Cr}$. Heavy metals in the study area could be categorized as $\mathrm{Cr}, \mathrm{Zn}$, and $\mathrm{Co}$ in the unpolluted category; $\mathrm{Cu}$ in slightly polluted; $\mathrm{Cd}$ and $\mathrm{Pb}$ in moderate polluted; and $\mathrm{Ni}$ in moderate sever polluted category Table 6.

Table 6. Geo accumulation index and enrichment factor.

\begin{tabular}{ccccc}
\hline Parameters & Igeo Min & Igeo Max & Igeo Mean & EF \\
\hline $\mathrm{Cr}$ & -0.13 & 0.03 & -0.04 & 0.39 \\
$\mathrm{Cd}$ & 2.53 & 3.90 & 2.72 & 0.65 \\
$\mathrm{~Pb}$ & 0.15 & 3.55 & 1.93 & 3.44 \\
$\mathrm{Ni}$ & 0.15 & 3.47 & 3.23 & 8.45 \\
$\mathrm{Cu}$ & 0.95 & 1.9 & 1.11 & 0.56 \\
$\mathrm{Zn}$ & -0.08 & 1.4 & 0.02 & 0.36 \\
$\mathrm{Co}$ & 0.29 & 1.6 & 0.14 & 0.35 \\
\hline
\end{tabular}

The enrichment factor is given in the Table 6. Six categories were recognized on the basis of enrichment factor Table 5 namely EF ( $\leq 1$ : as background rank, $1-2$ : as minimal, 2-5: as moderate, 5-20: as significant, 20-40: very high, and above 40: extremely high enrichment. The EF for $\mathrm{Cr}, \mathrm{Cd}, \mathrm{Pb}, \mathrm{Ni}, \mathrm{Cu}, \mathrm{Zn}$, Co were $0.39,0.65,3.44,8.45,0.56,0.36$, and 0.35 respectively. Among these elements, $\mathrm{Pb}$ and $\mathrm{Ni}$ were in enriched range while $\mathrm{Cr}, \mathrm{Cd}$, $\mathrm{Cu}, \mathrm{Zn}$, and Co were depleted in the study area Table 7. 
Table 7. Summary of statistical methods.

\begin{tabular}{ccc}
\hline Parameters & Geo Accumulation Index & EF Class \\
\hline $\mathrm{Cr}$ & Unpolluted & Depleted \\
$\mathrm{Cd}$ & Moderate polluted & Depleted \\
$\mathrm{Pb}$ & Moderate polluted & Enriched \\
$\mathrm{Ni}$ & Moderate sever polluted & Enriched \\
$\mathrm{Cu}$ & Slightly polluted & Depleted \\
$\mathrm{Zn}$ & Unpolluted & Depleted \\
$\mathrm{Co}$ & Unpolluted & Depleted \\
\hline
\end{tabular}

On the basis of statistical analysis (Figure 9), such as geo accumulation index and enrichment factor, it has been noticed that the soil of the study area has been affected by soild waste. The solid waste is composed of mainly domestic waste, and a small portion is commercial as confirmed by geophysical results in Section 4.1. To confirm the source of commercial waste, various commercial activities and operational units such as pharmaceutical companies, steel industry, leather, cement, clothes industry, and food processing and beverages industry in the premises of the study area were observed during the reconnaissance survey.
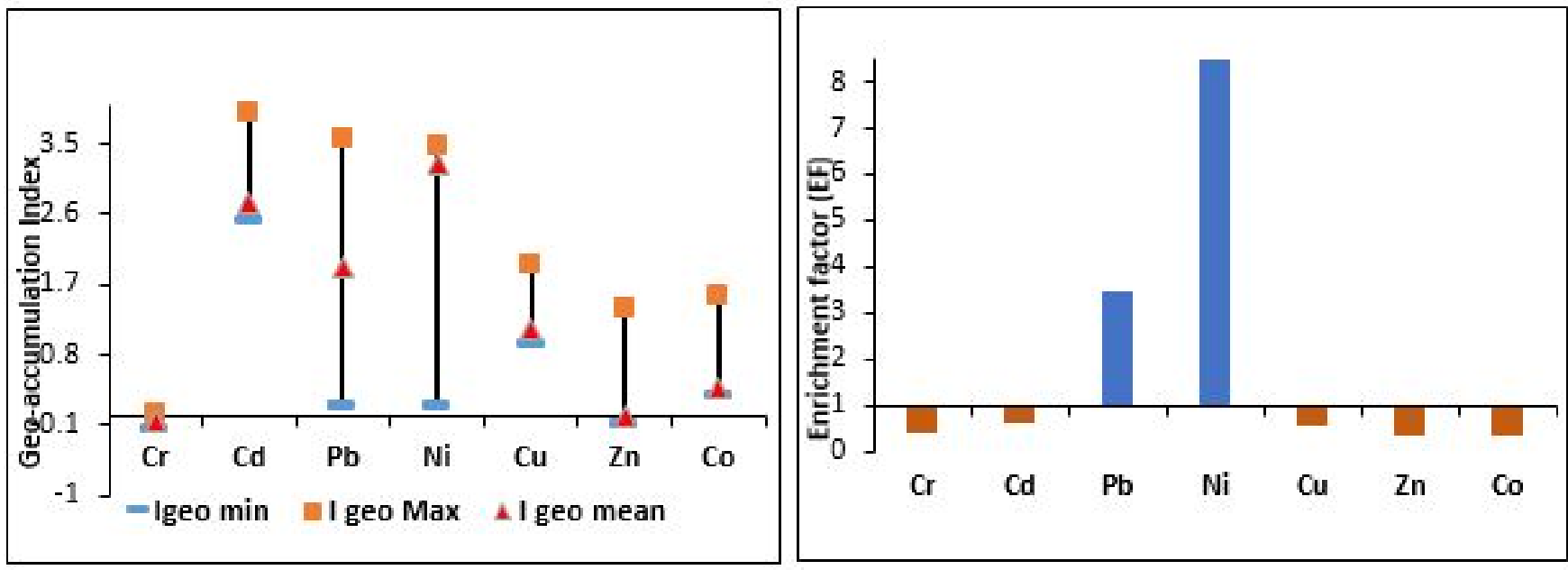

Figure 9. Geo-accumulation index and enrichment factor.

The studied HMs concentrations in study area were compared with the published geochemical results similar type from four different countries such as China, Italy, Pakistan, and Nigeria (Table 8). It was found that the concentrations of $\mathrm{Cr}, \mathrm{Pb}$, and $\mathrm{Zn}$ in the studied samples are lower while $\mathrm{Cu}, \mathrm{Ni}$, and $\mathrm{Cd}$ are higher than the open dumpsite situated in North China [52]. However, HMs concentrations around the dumpsite in Italy were found to be higher for all elements except $\mathrm{Cd}$ as compared to that of the studied samples [53]. The high rainfall $(900 \mathrm{~mm})$ could provide facilitation in leachate generation at the dumpsite of Italy as compared to the study area, with an average rainfall $420 \mathrm{~mm}$. Similarly, HMs concentrations of Mahmood Booti dumping site, Lahore, Pakistan were found lower than that of the studied samples [54]. Although the size of Mahmood Booti dumpsite is larger than the study area, the Mahmood Booti dumpsite was authorized as a dumpsite under the city district government Lahore (CDGL) and Turk company Oz Pak. The dumpsite was operated under proper vigilance as compare to Chowa Gujar dumpsite. The concentrations of $\mathrm{Pb}, \mathrm{Cd}, \mathrm{Ni}$, and $\mathrm{Zn}$ in the dumpsites in Islamabad, Pakistan were found to be higher than that of the studied samples [55], because $96 \%$ of total domestic, commercial, and industrial waste generated was dumped at this site. High volume of waste as compared to the study site could be the reason for high contamination concentration. In Nigeria, HMs concentration at dumpsite were found to be higher for $\mathrm{Cd}, \mathrm{Cr}, \mathrm{Ni}$, and $\mathrm{Pb}$ while lower 
for $\mathrm{Zn}$ as compared to that of the studied samples [56]. Electronic waste was dumped at this site, while the waste dumped at Chowa Gujar was heterogeneous as confirmed by the geophysical survey discussed in Section 4.1. Therefore, waste type could be the reason for high HMs concentration at dumpsite of Nigeria. HMs concentration of Chifing, Inner Mongolia China dumpsite were found to be higher for $\mathrm{Pb}$ and $\mathrm{Zn}$, and lower for $\mathrm{Cd}$ and $\mathrm{Cu}$ compared to the concentration of HMs in study area [57]. The concentrations of $\mathrm{Pb}$ and $\mathrm{Zn}$ were high because the survey was conducted around the non-ferrous mining waste dump.

Table 8. Comparative study of HMs concentration $(\mathrm{mg} / \mathrm{kg})$ mean values at Chowa Gujar dumpsite with other dumpsites in the world.

\begin{tabular}{|c|c|c|c|c|c|c|c|c|c|}
\hline Study Area & $\begin{array}{c}\text { Dumpsite } \\
\text { Description }\end{array}$ & $\mathrm{Cr}$ & $\mathrm{Cd}$ & $\mathrm{Pb}$ & $\mathrm{Ni}$ & $\mathrm{Cu}$ & $\mathrm{Zn}$ & Co & References \\
\hline Current Study & Municipal & 26.11 & 5.17 & 14.075 & 35.225 & 58.545 & 69.23 & 23.255 & - \\
\hline North China & Municipal & 76.35 & 0.38 & 26.74 & 31.82 & 30.49 & 120.16 & NR & [52] \\
\hline $\begin{array}{l}\text { Italy } \\
\text { Ial }\end{array}$ & Municipal & 84.7 & 0.46 & 39.3 & 73.4 & 68.7 & 127 & NR & [53] \\
\hline $\begin{array}{l}\text { Lahore, } \\
\text { Pakistan }\end{array}$ & Municipal & 2.42 & 3.30 & 10.82 & 8.97 & 18.67 & 34.69 & NR & [54] \\
\hline $\begin{array}{l}\text { Islamabad, } \\
\text { Pakistan }\end{array}$ & Municipal & 0.85 & 11.92 & 67.06 & 27.15 & 9.46 & 196.99 & & [55] \\
\hline $\begin{array}{l}\text { Nigeria } \\
\text { Phifing }\end{array}$ & Electronics & 46.58 & 9.99 & 630.07 & 85.43 & NR & 54.66 & NR & [56] \\
\hline $\begin{array}{l}\text { Chifing, Inner } \\
\text { Mongolia } \\
\text { China }\end{array}$ & Mining & NR & 1.01 & 96.47 & NR & 33.47 & 254.64 & NR & [57] \\
\hline
\end{tabular}

\section{Conclusions}

The Chowa Gujar dumpsite in the City of Peshawar is the model study site. This study characterized the MSW dumpsite by employing geophysical and geochemical methods. ERT models showed different stratigraphic layers and geometry of the waste dump in the sub-surface. High-resolution ERT sections provided accurate results by distinguishing the waste type, waste pockets, the thickness of waste contained zone, and sub-surface distribution of the associated leachate plume in the vicinity of the dumpsite. ERT results showed leachate contaminant plumes that are extended up to a depth range of $8 \mathrm{~m}$ and $14 \mathrm{~m}$ from the south and east edges of the dumpsite. GPR did not permit the deeper structure at the studied site to delineate the accurate vertical extension of the leachate plume or mapping migration pathways due to the strong attenuation of electromagnetic waves in the highly conductive zone. However, GPR data helped in demarcating lateral boundaries of different waste components and they have provided a positive correlation with ERT. Similarly, radar results have confirmed the isolated patches of very high conductive leachate-filled areas along a few profiles. Despite several factors (heterogeneous nature of waste material, moisture variations, lithological characteristics, and distance from the Bara River), the geophysical properties (electrical resistivity values $31-80 \Omega \mathrm{m}$ ) of the municipal waste were measured. The commercial waste was characterized by very high resistivity values $(80-127 \Omega \mathrm{m})$. The interpretation of the non-destructive geophysical data sets was made more accurate by comparing the results from GPR and ERT techniques. Geochemical data revealed that agricultural soil of study area is contaminated. The measured concentrations of HMs and geo-statistical results revealed that the soil of study area is contaminated. It is evident from the geophysical and geochemical assessment that Chowa Gujar dumpsite may pose an obvious threat to the agricultural soil and both surface and subsurface water in the study area, which could further deteriorate due to the continued dumping of a large volume of municipal and commercial wastes. Therefore, precautionary measures should be taken to avoid further contamination and keep the soil of the area environmentally sustainable for agricultural use. This study could be helpful to facilitate the policymakers and stake holders to develop the optimal strategies to restore the polluted dumpsite into a pollution free sustainable environment. 


\begin{abstract}
Author Contributions: Conceptualization, N.A.B. and M.Y.K.; methodology, G.A. and M.Y.K.; software, G.A. and N.A.B.; validation, G.A. and S.A.K.; formal analysis, M.Y.K., G.A. and M.T.S.; investigation, N.A.B. and A.F.; resources, G.A. and Y.G.; data curation, A.F. and S.A.K.; writing-original draft preparation, N.A.B.; writing-review and editing, G.A., A.F. and N.A.B.; visualization, M.Y.K., S.A.K. and Y.G.; supervision, M.Y.K. and M.T.S.; project administration, Y.G. and M.T.S.; funding acquisition, Y.G. and G.A. All authors have read and agreed to the published version of the manuscript.
\end{abstract}

Funding: This research is financially supported by the Chinese Academy of Sciences President's International Fellowship Initiative (Grant No. 2021VCA0010) and the International Science and Technology Cooperation Program of China (2018YFE0100100).

Institutional Review Board Statement: Not applicable.

Informed Consent Statement: Not applicable.

Data Availability Statement: Not applicable.

Acknowledgments: We would like to thank the anonymous reviewers and the Chinese Academy of Sciences President's International Fellowship Initiative plus the International Science \& Technology Cooperation Program of China who financially supported the current research. The Director of the National Centre of Excellence in Geology is highly acknowledged for providing laboratory facilities. Special thanks to the Executive Director of CPJRC for encouragement during the entire period of research.

Conflicts of Interest: The authors declare no conflict of interest.

\title{
References
}

1. United Nations. The Sustainable Development Goals; United Nations: New York, NY, USA, 2017.

2. United Nations. Revision of World Urbanization Prospects; United Nations: New York, NY, USA, 2018.

3. Goujon, A.; Wazir, A.; Gailey, N. Pakistan: A population giant falling behind in its demographic transition. Popul. Soc. 2020, 576, $1-4$.

4. Akmal, T.; Jamil, F. Assessing Health Damages from Improper Disposal of Solid Waste in Metropolitan Islamabad-Rawalpindi, Pakistan. Sustainability 2021, 13, 2717. [CrossRef]

5. Fetter, C.W.; Boving, T.; Kreamer, D. Contaminant Hydrogeology; Waveland Press: Long Grove, IL, USA, 2017.

6. Milad, Z.A. An Experimental Investigation of Landfill Leachate Impact on Surrounding Soil; Cardiff University: Cardiff, UK, 2014.

7. Hussein, M.; Yoneda, K.; Mohd-Zaki, Z.; Amir, A.; Othman, N. Heavy metals in leachate, impacted soils and natural soils of different landfills in Malaysia: An alarming threat. Chemosphere 2021, 267, 128874. [CrossRef]

8. Parvin, F.; Tareq, S.M. Impact of landfill leachate contamination on surface and groundwater of Bangladesh: A systematic review and possible public health risks assessment. Appl. Water Sci. 2021, 11, 100. [CrossRef]

9. Rusu, L.; Suceveanu, M.; Şuteu, D.; Favier, L.; Harja, M. Assessment of groundwater and surface water contamination by landfill leachate: A case study in Neamt county, Romania. Environ. Eng. Manag. J. 2017, 16, 633-641. [CrossRef]

10. Özel, S.; Yılmaz, A.; Emin Candansayar, M. The examination of the spread of the leachates coming out of a solid waste disposal area on the ground with geophysical and geochemical methods (Sivas, Turkey). Appl. Geophy. 2017, 138, 40-49. [CrossRef]

11. Fatoba, J.O.; Eluwole, A.B.; Sanuade, O.A.; Hammed, O.S.; Igboama, W.N.; Amosun, J.O. Geophysical and geochemical assessments of the environmental impact of Abule-Egba landfill, southwestern Nigeria. Model. Earth Syst. Environ. 2021, 7, 695-701. [CrossRef]

12. Kondracka, M.; Stan-Kłeczek, I.; Sitek, S.; Ignatiuk, D. Evaluation of geophysical methods for characterizing industrial and municipal waste dumps. J. Waste Manag. 2021, 125, 27-39. [CrossRef]

13. Atekwana, E.A.; Atekwana, E.A. Geophysical Signatures of Microbial Activity at Hydrocarbon Contaminated Sites: A Review. Surv. Geophy. 2010, 31, 247-283. [CrossRef]

14. Massarelli, C.; Campanale, C.; Uricchio, V.F. Ground Penetrating Radar as a Functional Tool to Outline the Presence of Buried Waste: A Case Study in South Italy. Sustainability 2021, 13, 3805. [CrossRef]

15. Ruffell, A.; Kulessa, B. Application of geophysical techniques in identifying illegally buried toxic waste. Environ. Forensics 2009, 10, 196-207. [CrossRef]

16. Porsani, J.L.; Filho, W.M.; Elis, V.R.; Shimeles, F.; Dourado, J.C.; Moura, H.P. The use of GPR and VES in delineating a contamination plume in a landfill site: A case study in SE Brazil. Appl. Geophy. 2004, 55, 199-209. [CrossRef]

17. Shao, S.; Gao, C.; Guo, X.; Wang, Y.; Zhang, Z.; Yu, L.; Tang, H. Mapping the contaminant plume of an abandoned hydrocarbon disposal site with geophysical and geochemical methods, Jiangsu, China. Environ. Sci. Pollut. Res. 2019, 26, 24645-24657. [CrossRef]

18. Park, S.; Yi, M.-J.; Kim, J.-H.; Shin, S.W. Electrical resistivity imaging (ERI) monitoring for groundwater contamination in an uncontrolled landfill, South Korea. Appl. Geophys. 2016, 135, 1-7. [CrossRef] 
19. Di Maio, R.; Fais, S.; Ligas, P.; Piegari, E.; Raga, R.; Cossu, R. 3D geophysical imaging for site-specific characterization plan of an old landfill. J. Waste Manag. 2018, 76, 629-642. [CrossRef]

20. Simyrdanis, K.; Papadopoulos, N.; Soupios, P.; Kirkou, S.; Tsourlos, P. Characterization and monitoring of subsurface contamination from Olive Oil Mills' waste waters using Electrical Resistivity Tomography. Sci. Total Environ. 2018, 637-638, 991-1003. [CrossRef]

21. Soupios, P.; Papadopoulos, N.; Papadopoulos, I.; Kouli, M.; Vallianatos, F.; Sarris, A.; Manios, T. Application of integrated methods in mapping waste disposal areas. Environ. Geol. 2007, 53, 661. [CrossRef]

22. Yannah, M.; Martens, K.; Van Camp, M.; Walraevens, K. Geophysical exploration of an old dumpsite in the perspective of enhanced landfill mining in Kermt area, Belgium. Bull. Eng. Geol. Environ. 2019, 78, 55-67. [CrossRef]

23. Burbank, D.W.; Tahirkheli, R.K. The magnetostratigraphy, fission-track dating, and stratigraphic evolution of the Peshawar intermontane basin, northern Pakistan. Geol. Soc. Am. Bull. 1985, 96, 539-552. [CrossRef]

24. Kruseman, G.P.; Naqavi, S.A.H. Hydrogeology and groundwater resources of the North-West Frontier Province Pakistan. In Hydrogeology and Groundwater Resources of the 71 North-West Frontier Province Pakistan. Water and Power Development Authority; TNO Institute for Applied Geoscience: Delft, The Netherland, 1988.

25. Searle, M.P.; Khan, M.A.S. Geological map of North Pakistan and adjacent areas of northern Ladakh and western Tibet: (Western Himalaya, Salt Ranges, Kohistan, Karakoram, Hindu Kush). Br. Geol. Surv. (BGS) 2001, 22, 115-117.

26. Cornwell, K.J. Evidence of Quaternary Break-Out Floods along the Middle Indus Valley and in the Peshawar Basin of Northern Pakistan; The University of Nebraska: Lincoln, NE, USA, 1994.

27. Nizami, M. Reconnaissance soil survey of Peshawar vale (revised). Soil Surv. Pak. Lahore 1973, 165, 145-165.

28. Tariq, S. Environmental Geochemistry of Surface and Sub Surface Water and Soil in Peshawar Basin of NWFP Pakistan. Ph.D. Thesis, University of Peshawar, Peshawar, Pakistan, 2001.

29. Salama, R.B.; Otto, C.J.; Fitzpatrick, R.W. Contributions of groundwater conditions to soil and water salinization. Hydrogeol. J. 1999, 7, 46-64. [CrossRef]

30. Ali, N. Groundwater Assessment of the Peshawar District and Its Potential for Future Demand; College of Science and Engineering, Flinders University: Adelaide, Australia, 2018.

31. Telford, W.M.; Telford, W.; Geldart, L.; Sheriff, R.E. Applied Geophysics; Cambridge University Press: Cambridge, UK, 1990.

32. Meju, M.A. Geoelectrical investigation of old/abandoned, covered landfill sites in urban areas: Model development with a genetic diagnosis approach. Appl. Geophys. 2000, 44, 115-150. [CrossRef]

33. Vásconez-Maza, M.D.; Bueso, M.C.; Faz, A.; Acosta, J.A.; Martínez-Segura, M.A. Assessing the behaviour of heavy metals in abandoned phosphogypsum deposits combining electrical resistivity tomography and multivariate analysis. J. Environ. Manag. 2021, 278, 111517. [CrossRef]

34. Loke, M.H.; Barker, R.D. Rapid least-squares inversion of apparent resistivity pseudosections by a quasi. Newton method1. Geophys. Prospect. 1996, 44, 131-152. [CrossRef]

35. Annan, A.; Davis, J.; Pilon, J. Design and development of a digital ground penetrating radar system. Ground Penetrating Radar Geol. Surv. Can. Spec. Pap. 1992, 90, 15-23.

36. Khan, M.Y.; Rehman, K.; Wajid, A.; Turab, S.A.; Latif, K.; Iqbal, S. Characterization of Ground Penerating Radar (GPR) wave response in shallow subsurface for forensic investigation in controlled environment. J. Himal. Earth Sci. 2019, 52, 58.

37. Khan, M.Y.; Shafique, M.; Turab, S.A.; Ahmad, N. Characterization of an Unstable Slope Using Geophysical, UAV, and Geological Techniques: Karakoram Himalaya, Northern Pakistan. Front. Earth Sci. 2021, 120, 705. [CrossRef]

38. Splajt, T.; Ferrier, G.; Frostick, L. Application of ground penetrating radar in mapping and monitoring landfill sites. Environ. Geol. 2003, 44, 963-967. [CrossRef]

39. Orlando, L.; Marchesi, E. Georadar as a tool to identify and characterise solid waste dump deposits. Appl. Geophys. 2001, 48, 163-174. [CrossRef]

40. Sandmeier, K.J. Reflexw 6.0 manual sandmeier software. Zipser Strabe. 2001, 1, 15-45.

41. United State Environmental Protection Agency. 1992. EPA preparation of soil sampling protocols: Sampling techniques and strategies. Off. Res. Dev. 1992, 128,1-17.

42. Atgin, R.S.; El-Agha, O.; Zararsız, A.; Kocataş, A.; Parlak, H.; Tuncel, G. Investigation of the sediment pollution in Izmir Bay: Trace elements. Spectrochim. Acta Part B At. Spectrosc. 2000, 55, 1151-1164. [CrossRef]

43. Wu, T.-N.; Huang, Y.-C. Detection of illegal dump deposit with GPR: Case study. Pract. Period. Hazard. Toxic Radioact. Waste Manag. 2006, 10, 144-149. [CrossRef]

44. Daily, W.; Ramirez, A.; LaBrecque, D.; Barber, W. Electrical resistance tomography experiments at the Oregon Graduate Institute. Appl. Geophys. 1995, 33, 227-237. [CrossRef]

45. Mao, D.; Revil, A.; Hort, R.D.; Munakata-Marr, J.; Atekwana, E.A.; Kulessa, B. Resistivity and self-potential tomography applied to groundwater remediation and contaminant plumes: Sandbox and field experiments. J. Hydrol. 2015, 530, 1-14. [CrossRef]

46. Wijewardana, N.; Galagedara, L.; Mowjood, M. Assessment of groundwater contamination by landfill leachate with ground penetrating radar. In Proceedings of the 2012 14th International Conference on Ground Penetrating Radar (GPR), Shanghai, China, 4-8 June 2012; pp. 728-732.

47. Shemang, E.; Mickus, K.; Same, M. Geophysical characterization of the abandoned gaborone landfill, Botswana: Implications for abandoned landfills in arid environments. Int. J. Environ. Prot. 2011, 1, 1-12. 
48. Wijewardana, Y.; Shilpadi, A.; Mowjood, M.; Kawamoto, K.; Galagedara, L. Ground-penetrating radar (GPR) responses for sub-surface salt contamination and solid waste: Modeling and controlled lysimeter studies. Environ. Monit. Assess. 2017, 189, 57. [CrossRef]

49. Canadian Council of Ministers of the Environment (CCME). Canadian Council of Ministers of the Environment). Canadian Soil Quality Guidelines for the Protection of Environmental and Human Health: Summary Tables Updated 7.0, September, 2007. In Canadian Environmental Quality Guidelines; Canadian Council of Ministers of the Environment: Winnipeg, MB, Canada, 2007.

50. CEPA. Environmental Quality Standard for Soils. GB15618-1995; Chinese Environmental Protection Administration: Beijing, China, 1995.

51. Hussain, R.; Luo, K.; Chao, Z.; Xiaofeng, Z. Trace elements concentration and distributions in coal and coal mining wastes and their environmental and health impacts in Shaanxi, China. Environ. Sci. Pollut. Res. 2018, 25, 19566-19584. [CrossRef]

52. Ma, W.; Tai, L.; Qiao, Z.; Zhong, L.; Wang, Z.; Fu, K.; Chen, G. Contamination source apportionment and health risk assessment of heavy metals in soil around municipal solid waste incinerator: A case study in North China. Sci. Total Environ. 2018, 631, 348-357. [CrossRef]

53. Bretzel, F.C.; Calderisi, M. Contribution of a municipal solid waste incinerator to the trace metals in the surrounding soil. Environ. Monit. Assess. 2011, 182, 523-533. [CrossRef] [PubMed]

54. Aiman, U.; Mahmood, A.; Waheed, S.; Malik, R.N. Enrichment, geo-accumulation and risk surveillance of toxic metals for different environmental compartments from Mehmood Booti dumping site, Lahore city, Pakistan. Chemosphere 2016, 144, $2229-2237$. [CrossRef] [PubMed]

55. Ali, S.M.; Pervaiz, A.; Afzal, B.; Hamid, N.; Yasmin, A. Open dumping of municipal solid waste and its hazardous impacts on soil and vegetation diversity at waste dumping sites of Islamabad city. J. King Saud Univ. Sci. 2014, 26, 59-65. [CrossRef]

56. Olafisoye, O.B.; Adefioye, T.; Osibote, O.A. Heavy Metals Contamination of Water, Soil, and Plants around an Electronic Waste Dumpsite. Pol. J. Environ. Stud. 2013, 22, 1431-1439.

57. Hu, Z.; Wang, C.; Li, K.; Zhu, X. Distribution characteristics and pollution assessment of soil heavy metals over a typical nonferrous metal mine area in Chifeng, Inner Mongolia, China. Environ. Earth. Sci. 2018, 77, 638. [CrossRef] 